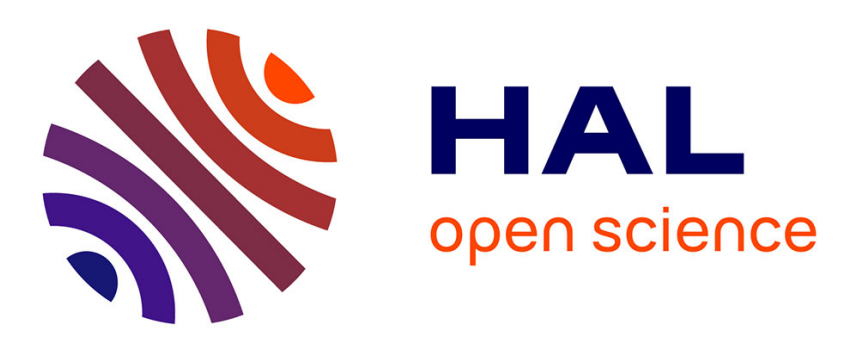

\title{
The North Atlantic Waveguide and Downstream Impact Experiment
}

Andreas Schäfler, Maxi Craig, Heini Wernli, Philippe Arbogast, James Doyle, Ron Mctaggart-Cowan, John Methven, Gwendal Rivière, Felix Ament, Maxi

Boettcher, et al.

\section{To cite this version:}

Andreas Schäfler, Maxi Craig, Heini Wernli, Philippe Arbogast, James Doyle, et al.. The North Atlantic Waveguide and Downstream Impact Experiment. Bulletin of the American Meteorological Society, 2018, 99 (8), pp.1607-1637. 10.1175/BAMS-D-17-0003.1 . insu-01760458

\section{HAL Id: insu-01760458 https://hal-insu.archives-ouvertes.fr/insu-01760458}

Submitted on 19 Aug 2020

HAL is a multi-disciplinary open access archive for the deposit and dissemination of scientific research documents, whether they are published or not. The documents may come from teaching and research institutions in France or abroad, or from public or private research centers.
L'archive ouverte pluridisciplinaire $\mathbf{H A L}$, est destinée au dépôt et à la diffusion de documents scientifiques de niveau recherche, publiés ou non, émanant des établissements d'enseignement et de recherche français ou étrangers, des laboratoires publics ou privés. 


\section{THE NORTH ATLANTIC WAVEGUIDE AND DOWNSTREAM IMPACT EXPERIMENT}

Andreas Schäfler, George Craig, Heini Wernli, Philippe Arbogast, James D. Doyle, Ron Mctaggart-Cowan, John Methven, Gwendal Rivière, Felix Ament, Maxi Boettcher, Martina Bramberger, Quitterie Cazenave, Richard Cotton, Susanne Crewell, Julien Delanoë, Andreas Dörnbrack, André Ehrlich, Florian Ewald, Andreas Fix, Christian M. Grams, Suzanne L. Gray, Hans Grob, Silke Groß, Martin Hagen, Ben Harvey, lutz Hirsch, Marek Jacob, Tobias Kölling, Heike Konow, Christian Lemmerz, Oliver lux, Linus Magnusson, Bernhard Mayer, Mario Mech, Richard Moore, Jacques Pelon, Julian Quinting, Stephan Rahm, Markus Rapp, Marc Rautenhaus, Oliver Reitebuch, Carolyn A. Reynolds, Harald Sodemann, Thomas Spengler, Geraint Vaughan, Manfred Wendisch, Martin Wirth, Benjamin Witschas, Kevin Wolf, and Tobias Zinner

Multiaircraft and ground-based observations were made over the North Atlantic in the fall of 2016 to investigate the importance of diabatic processes for midlatitude weather.

$\mathrm{P}$ rogress in understanding the processes controlling midlatitude weather is one of the factors that have contributed to a continuous improvement in the skill of medium-range weather forecasts in recent decades (Thorpe 2004; Richardson et al. 2012; Bauer et al. 2015). Additionally, numerical weather prediction (NWP) has undergone a revolution in recent years, with the development and widespread use of ensemble prediction systems (EPSs) to represent forecast uncertainty (Bauer et al. 2015). However, the short-term prediction of high-impact weather (HIW) events (e.g., strong winds and heavy precipitation), and the medium-range prediction of extratropical cyclones, including their tracks and intensity, are still major challenges (e.g., Frame et al. 2015). Recent research into midlatitude weather has focused on quantifying model errors and predictability, and in particular on investigating the role of diabatic processes such as those related to clouds and radiation, whose interaction with the dynamics of the flow must be understood and represented more accurately in models in order to further improve forecast quality.
Detailed observations are needed to characterize the weather systems and embedded physical processes across a range of spatial and temporal scales that encompass cloud microphysical variability and Rossby waves. In September and October 2016, the North Atlantic Waveguide and Downstream Impact Experiment (NAWDEX) made new multiscale observations in the North Atlantic basin from eastern Canada to western Europe. Weather features expected to be associated with forecast errors were extensively probed, providing a high-quality set of observations that are not assimilated routinely and thus can be used for validation of the NWP systems.

The fall season was chosen for the experiment because diabatic processes are particularly active as a result of relatively high sea surface temperatures and the intensification of the jet stream as the high latitudes cool. Many of the weather phenomena central to the growth of disturbances on the jet stream and midlatitude predictability are active in fall, such as extratropical cyclones with intense fronts and warm conveyor belts (WCBs), carrying air from the oceanic 
boundary layer into ridges at the tropopause level. There is also the possibility of North Atlantic tropical cyclones (TCs) recurving poleward into midlatitudes and undergoing extratropical transition (ET), which is a process known to be associated with low predictability (Harr et al. 2000). Coherent mesoscale depressions of the tropopause, known as tropopause polar vortices (TPVs; Cavallo and Hakim 2010; Kew et al. 2010), can disturb the jet stream if they move equatorward from the Arctic.

NAWDEX contributes to the World Weather Research Programme (WWRP) and its High Impact Weather project (Jones and Golding 2015) and aims to provide the observational foundation to further investigate cloud diabatic processes and radiative transfer in North Atlantic weather systems, which will form the basis for future improvements in the prediction of HIW over Europe.

THE ROLE OF DIABATIC PROCESSES. Weather in Europe strongly depends on the life cycles of Rossby waves that propagate along the slowly varying part of the North Atlantic jet stream (Martius et al. 2010). The strong meridional potential vorticity (PV) gradient associated with the jet stream serves as a waveguide for propagating Rossby waves. Frequently, small disturbances in the jet entrance region over eastern North America grow in baroclinic weather systems and evolve into large-amplitude features in the European sector (Schwierz et al. 2004). Figure 1 portrays an idealized North Atlantic flow situation that could result in HIW in the form of high winds and heavy precipitation over northern Europe. In addition to Rossby waves amplifying through baroclinic instability, diabatic processes are able to modify upper-tropospheric PV at the level of the midlatitude jet stream, which impacts the wavelength and amplitude of the downstream Rossby wave development (e.g., Massacand et al. 2001; Knippertz and Martin 2005; Grams et al. 2011; Teubler and Riemer 2016).

The majority of the precipitation and cloud diabatic processes in extratropical cyclones occur within a coherent airstream known as the WCB. It carries warm, moist air from the low-level warm sector of a cyclone to the ridge at tropopause level within 1-2 days (Browning et al. 1973; Carlson 1980; Wernli and Davies 1997). The boundary layer humidity in the inflow of WCBs (region 1 in Fig. 1) can impact the outflow height of WCBs (Schäfler and Harnisch 2015). For some WCBs, the inflow region coincides with a filament of strong horizontal water vapor transport, a so-called atmospheric river, which can contribute to intense rain in the midlatitudes (Lavers and Villarini 2013). During the ascent of WCBs (region 2 in Fig. 1), embedded convection, and turbulent fluxes influence the level of the outflow layer, the direction taken by outflow air masses, and the shape of the upper-level ridge (Martínez-Alvarado et al. 2014; Joos and Forbes 2016). The latent heating in WCBs is strong both in the early phase of the ascent when condensation dominates and later when mixed-phase clouds are formed and vapor deposition on ice crystals and snow becomes important (Joos and Wernli 2012).
AfFiliations: Schäfler, Bramberger, Dörnbrack, EWALD, Fix, Groß, hagen, Lemmerz, Lux, Rahm, Rapp, Reitebuch, Wirth, AND WITSChAS-Deutsches Zentrum für Luft- und Raumfahrt, Oberpfaffenhofen, Germany; CRAIG, GroB, KölLING, MAYER, AND ZINNER-Ludwig-Maximilians-Universität, Munich, Germany; Wernli, Boettcher, and Grams-ETH Zürich, Zurich, Switzerland; ARbogast-CNRM, Météo-France/CNRS, Toulouse, France; DOYLE AND REYNOLDS—Naval Research Laboratory, Monterey, California; MCTAGgaRt-CowaN-Environment and Climate Change Canada, Dorval, Quebec, Canada; Methren, Gray, AND HARVEY-Department of Meteorology, University of Reading, Reading, United Kingdom; RIVIÈRE-LMD/IPSL, ENS/PSL Research University/CNRS, Paris, France; AMENT AND KonOw-Universität Hamburg, and Max Planck Institute for Meteorology, Hamburg, Germany; Cazenave, Delanoë, and Pelon-Laboratoire Atmosphère, Milieux, et Observations Spatiales, Guyancourt, France; Cotton- Met Office, Exeter, United Kingdom; Crewell, JACOB, AND MECH—Universität Köln, Cologne, Germany; EHRLICH, WeNDISCH, AND WoLf-Universität Leipzig, Leipzig, Germany; HIRSCH—Max Planck Institute for Meteorology, Hamburg,
Germany; MAGNusson-European Centre for Medium-Range Weather Forecasts, Reading, United Kingdom; MOORENorwegian Meteorological Institute, and University of Oslo, Oslo, Norway; QUINTING-ETH Zürich, Zurich, Switzerland, and Monash University, Clayton, Victoria, Australia; RautenhausTechnische Universität München, Garching, Germany; SOdEMANN AND SPENGLER-Geophysical Institute, University of Bergen, and Bjerknes Centre for Climate Research, Bergen, Norway; VAUGHAN-National Centre for Atmospheric Science, University of Manchester, Manchester, United Kingdom CORRESPONDING AUTHOR: Dr. Andreas Schäfler, andreas.schaefler@dlr.de

The abstract for this article can be found in this issue, following the table of contents.

DOI:10.II75/BAMS-D-I7-0003.I

In final form 17 January 2018

(C)2018 American Meteorological Society

For information regarding reuse of this content and general copyright information, consult the AMS Copyright Policy. 
The effect of the heating on the PV structure is to produce a positive $\mathrm{PV}$ anomaly in the lower troposphere (Wernli and Davies 1997), which influences the structure and evolution of midlatitude surface cyclones (e.g., Kuo et al. 1991; Davis et al. 1993; Binder et al. 2016). Above the level of maximum latent heating, $\mathrm{PV}$ is reduced by cloud diabatic processes, leading to negative PV anomalies in the upper-tropospheric WCB outflow region (Wernli 1997; Pomroy and Thorpe 2000; Madonna et al. 2014; Methven 2015). The divergent outflow winds (region 3 in Fig. 1) tend to amplify the upperlevel downstream ridge and

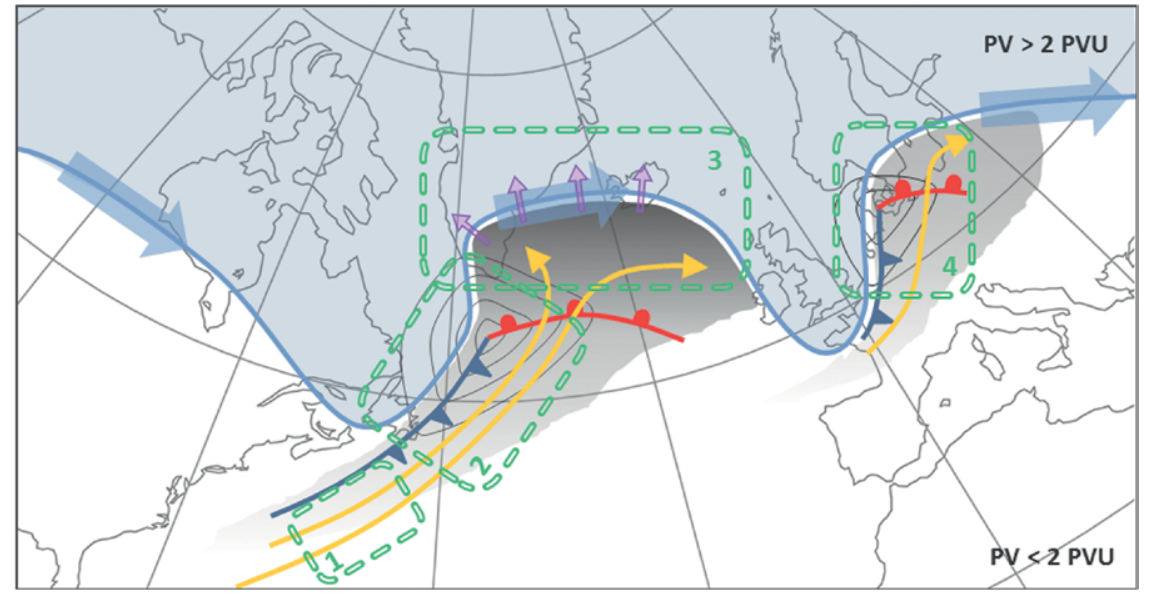

FIG. I. Schematic of an idealized weather situation during NAWDEX. The blue line marks the location of the waveguide with a strong isentropic PV gradient separating stratospheric (blue background; PV > 2 PV units (PVU; I PVU = $10^{-6} \mathrm{~K} \mathrm{~kg}^{-1} \mathrm{~m}^{2} \mathrm{~s}^{-1}$ ] from tropospheric air (white background). The jet stream (dark blue arrows) follows the waveguide. Surface lows develop below the leading edge of upper-level positive PV anomalies (gray lines indicate sea level pressure and dark blue and red lines surface cold and warm fronts, respectively). Gray-shaded areas indicate clouds related to ascending WCBs (yellow arrows). Purple arrows mark divergent outflow at the tropopause. The four green boxes outline the main regions of interest: the inflow (I), ascent (2), and outflow (3) of WCBs, as well as a region of expected downstream impact (4). to intensify the jet stream by strengthening the PV gradient (Archambault et al. 2013). If the outflow layer is higher, the negative PV anomaly is stronger and more of the air mass enters the anticyclonic branch of the WCB flowing into the downstream ridge (Grams and Archambault 2016). In addition, a sharp peak in longwave radiative cooling near the tropopause, associated with a step change in water vapor, creates a reinforcement of the positive $\mathrm{PV}$ anomaly in upper-level troughs (Chagnon et al. 2013) and plays a key role in maintaining and strengthening TPVs (Cavallo and Hakim 2012).

Diabatic processes also play a key role in weather systems that act as triggers to disturb the midlatitude waveguide. Recurving TCs undergoing ET (Jones et al. 2003) can enhance the anticyclonic and divergent flow at upper levels, excite and amplify Rossby waves, and cause downstream forecast errors, as well as HIW events (e.g., Agusti-Panareda et al. 2004; Harr et al. 2000; Riemer and Jones 2010). Radiatively maintained TPVs, which are positive PV anomalies above the tropopause, can disturb the Rossby waveguide from the polar latitudes.

Rossby wave breaking leads to PV filamentation, forming smaller-scale PV anomalies such as PV streamers and cutoff vortices. They form frequently over the eastern North Atlantic and Europe (e.g., Wernli and Sprenger 2007), and several studies have reported their relevance for triggering HIW,

in particular heavy precipitation (e.g., Martius et al. 2006; Chaboureau and Claud 2006; Grams and Blumer 2015). Synoptic wave breaking events are also important for the large-scale flow itself as they reinforce weather regimes such as blocking ridges (Michel and Rivière 2011; Spensberger and Spengler 2014). Blocks are also strongly influenced by diabatic processes in air masses ascending from the lower troposphere (Pfahl et al. 2015).

Disturbances of the waveguide and associated errors can amplify and propagate downstream, and may cause significant forecast errors over Europe (Madonna et al. 2015; Martínez-Alvarado et al. 2016) (region 4 in Fig. 1). In NWP models, diabatic processes such as those associated with convection, cloud microphysics, and radiation are represented by parameterizations of varying degrees of fidelity and may contain both systematic and random errors that influence forecast skill. A distinct Rossby wave pattern associated with the poleward transport of warm and moist air over the eastern United States and strong diabatic activity has been identified as a common precursor 6 days before the worst forecast busts over Europe (Rodwell et al. 2013). Upscale error growth experiments in numerical models show that the growth of small-scale perturbations is initially confined to regions where condensation is occurring, with the regions of large error amplitude gradually 
expanding to affect the synoptic-scale weather pattern (Zhang et al. 2007; Selz and Craig 2015). Doyle et al. (2014) found forecasts of an extratropical cyclone with severe impacts in western Europe to be very sensitive to the initial low-level moisture, which influenced the moisture supply in a WCB. At upper levels, global NWP models fail to maintain a sufficiently sharp tropopause, showing a decrease in sharpness with forecast lead time (Gray et al. 2014). This influence on the waveguide can have major implications for the representation of the downstream propagation and amplification of Rossby waves in NWP (Harvey et al. 2016) and the associated prediction of HIW.

Previous studies using measurements to study the influence of diabatic processes on the Rossby waveguide have been primarily based on routinely collected observations by operational meteorological services. These observations rely largely on satellite data, which models predominantly assimilate in cloud-free areas, and on sparse in situ measurements, all of which are combined in the data assimilation system using model forecasts as a background estimate. This approach to studying diabatic processes has significant limitations since these processes tend to be strongest in cloudy and precipitating regions, which are particularly challenging for both observation and modeling systems. The processes associated with diabatic heating are characterized by a high degree of small-scale variability, particularly in the vertical (e.g., sharp vertical gradients of cloud microphysical processes and their interactions with radiative forcing), which are typically poorly resolved by satellite and conventional in situ observations. Furthermore, rapid error growth and systematic model errors lead to large errors in the background forecast in precisely these regions, which are poorly characterized by error covariance matrices based on climatology and/or sampling using an ensemble of limited size. A field campaign has the potential to address some of these difficulties by deploying specialized observing systems with high resolution and the ability to measure both in and around clouds.

NAWDEX was proposed with the overarching hypothesis that diabatic processes have a major influence on the jet-stream structure, the downstream development of Rossby waves, and eventually HIW. Specific science goals were formulated (Table 1), which require observations of moisture advection in the boundary layer and of the vertical distribution of stability, water vapor, liquid droplets, and ice crystals. These observations will be used to investigate spatial variability within clouds and the implications for diabatic processes. Detailed wind measurements in the layer of the divergent outflow of the WCB are needed to investigate the interaction of diabatically modified air masses with the upper-level jet. This includes observations of horizontal and vertical gradients of wind, temperature, and humidity, as well as hydrometeors in clouds. Accordingly, highresolution cross sections of wind, temperature, and humidity from the lower stratosphere down to the surface, inside and outside of clouds, are the central observational requirements, which are not available from conventional observations.

\section{EXPERIMENTAL DESIGNAND} OBSERVATIONS. The need for a new field experiment emerged from a series of campaigns coordinated by the World Meteorological Organization's The Observing System Research and Predictability Experiment (THORPEX; Parsons et al. 2017). This series includes the Atlantic THORPEX Regional Campaign (ATReC; Rabier et al. 2008), Winter Storm Reconnaissance (WSR, e.g., Szunyogh et al. 2000), the THORPEX Pacific Asian Regional Campaign (T-PARC, Weissmann et al. 2011), and the Convective and Orographically Induced Precipitation Study/ European THORPEX Regional Campaign (COPS/ ETReC 2007; Wulfmeyer et al. 2011), which all focused on the impact of additional observations on improving forecast accuracy. This idea was pioneered by the Fronts and Atlantic Storm Track Experiment (FASTEX) in 1997 (Joly et al. 1999), where the concept of targeting observations using sensitive area calculations was introduced. The synthesis of these campaigns and data assimilation experiments denying observations in data-rich areas showed that the impact of targeted observations on global forecast systems is weaker than originally anticipated, although they improve forecasts on average [see review by Majumdar (2016)]. At the same time, as discussed above, evidence was growing that forecast errors often originate in regions where diabatic processes are strong and observation and modeling systems are least reliable. This provided the motivation for a new campaign, NAWDEX, that rather than targeting regions of forecast sensitivity, instead focused on observing the processes that are thought to be most uncertain in NWP models.

Diabatic processes are difficult to measure directly but can be constrained via their observable effects on the structure and evolution of weather systems. In the decade before THORPEX, detailed diagnostic case studies using aircraft measurements [e.g., Experiment on Rapidly Intensifying Cyclones over the Atlantic (ERICA; Hadlock and Kreitzberg 1988) 
TABLE I. NAWDEX research aims and science goals. Region numbers refer to Fig. I.

\begin{tabular}{|c|c|c|c|}
\hline Aim No. & Topic & Science goals & Region \\
\hline \multirow{2}{*}{ I } & \multirow{2}{*}{ Moisture structure in the boundary layer } & $\begin{array}{l}\text { Characterization of low-level moisture in } \\
\text { atmospheric rivers and WCB inflow regions }\end{array}$ & \multirow{2}{*}{$\mathrm{I},(2,3), 4$} \\
\hline & & $\begin{array}{l}\text { Impact of low-level moisture on downstream weather } \\
\text { evolution }\end{array}$ & \\
\hline \multirow{4}{*}{2} & \multirow{4}{*}{ Mixed-phase and cirrus clouds } & $\begin{array}{l}\text { In situ and remote sensing measurements of cloud } \\
\text { properties and meteorological parameters during } \\
\text { WCB ascent and outflow }\end{array}$ & \multirow{4}{*}{2,3} \\
\hline & & $\begin{array}{l}\text { Comparison of observations and models to quantify } \\
\text { latent and radiative heating/cooling in and below WCB }\end{array}$ & \\
\hline & & $\begin{array}{l}\text { Role of slantwise ascent vs embedded convection in } \\
\text { WCB }\end{array}$ & \\
\hline & & $\begin{array}{l}\text { Characterization of vertical moisture gradient and } \\
\text { cirrus structure in WCB outflow and effects on } \\
\text { radiation }\end{array}$ & \\
\hline \multirow{5}{*}{3} & \multirow{5}{*}{ Potential vorticity } & Quantitative estimate of PV from observations & \multirow{5}{*}{3} \\
\hline & & $\begin{array}{l}\text { Verification of PV structures, PV gradients, and } \\
\text { jet-stream winds in numerical models }\end{array}$ & \\
\hline & & $\begin{array}{l}\text { Structure of negative PV anomalies in WCB outflows } \\
\text { and upper-tropospheric ridges }\end{array}$ & \\
\hline & & $\begin{array}{l}\text { Role of divergent outflow of WCBs for ridge } \\
\text { amplification }\end{array}$ & \\
\hline & & $\begin{array}{l}\text { Spatial distribution of turbulence in the free } \\
\text { atmosphere and relationship to jet-stream and } \\
\text { PV structures }\end{array}$ & \\
\hline \multirow[b]{2}{*}{4} & \multirow{2}{*}{$\begin{array}{l}\text { Tropopause waveguide, predictability, } \\
\text { and consequences for HIW }\end{array}$} & $\begin{array}{l}\text { Relevance of amplifying small errors at tropopause } \\
\text { level for uncertainty in surface weather downstream }\end{array}$ & \multirow[b]{2}{*}{3,4} \\
\hline & & $\begin{array}{l}\text { Influence of observations within and outside of } \\
\text { diabatically active regions on the predictability of } \\
\text { downstream HIW }\end{array}$ & \\
\hline \multirow{7}{*}{5} & \multirow{7}{*}{ Instrument-driven aims } & $\begin{array}{l}\text { Comparison of measured radiances and retrieved } \\
\text { cloud optical properties between the Spectral Modular } \\
\text { Airborne Radiation Measurement System } \\
\text { (SMART)-HALO and Cloud Spectrometer of the } \\
\text { Munich Aerosol Cloud Scanner (specMACS) }\end{array}$ & \multirow{7}{*}{2,3} \\
\hline & & $\begin{array}{l}\text { Cloud regime characterization in midlatitude } \\
\text { cyclones and analysis of model representation at } \\
\text { different resolutions }\end{array}$ & \\
\hline & & $\begin{array}{l}\text { Radiometer retrieval development for profiles and } \\
\text { hydrometeor paths using instrument synergies }\end{array}$ & \\
\hline & & $\begin{array}{l}\text { Validation of Aeolus calibration and wind retrieval } \\
\text { algorithms }\end{array}$ & \\
\hline & & $\begin{array}{l}\text { Intercomparison of wind and aerosol products from } \\
\text { different instruments on DLR and SAFIRE Falcon }\end{array}$ & \\
\hline & & First test of the Earth Clouds, Aerosols and & \\
\hline & & $\begin{array}{l}\text { Radiation Explorer (EarthCARE) calibration and } \\
\text { validation strategy }\end{array}$ & \\
\hline
\end{tabular}

and FASTEX] had already shown that diabatic processes, in particular diabatic heating and cooling, can impact the large-scale dynamics via PV modification
(Neiman et al. 1993; Pomroy and Thorpe 2000). However, the processes are difficult to accurately quantify since they depend on finescale structures 
(e.g., sharp gradients) in the water vapor and cloud fields and are influenced by transport and mixing over a wide range of spatial and temporal scales throughout the lifetime of the cyclone (recall Fig. 1). Two single-aircraft field campaigns organized within THORPEX explored how aircraft observations could be used to accurately constrain the impact of diabatic heating in midlatitude cyclones. The Diabatic Influence on Mesoscale Structures in Extratropical Storms (DIAMET) experiment (Vaughan et al. 2015) made airborne in situ measurements of liquid droplets and ice crystals and used them to infer the microphysical processes acting, their positions relative to mesoscale structures (such as fronts and PV anomalies), and their role in the weather system dynamics. Although the observations were limited to the one-dimensional
(1D) aircraft flight path, they provided a basis for the modeling studies of Dearden et al. (2014), who obtained estimates of heating rates from various microphysical processes represented by a Lagrangian model initialized with in situ observations of size distributions for cloud droplets and ice particles. However, using a model to extrapolate the measurement information in space and time represents an additional source of uncertainty in the quantification of the processes. The THORPEX-NAWDEX-Falcon project (Schäfler et al. 2014) attempted to constrain this uncertainty by carrying out in situ observations of clouds, humidity, and wind in ascending WCBs, and trying to resample the same air masses at a later time to obtain a Lagrangian estimate of the integrated diabatic effects. NAWDEX was conceived to expand

ACTIVE REMOTE SENSING OBSERVATIONS FOR FUTURE SATELLITE MISSIONS AEOLUS AND EARTHCARE

$H^{\prime \prime O}$ ALO and the SAFIRE and DLR Falcon aircraft were equipped with remote sensing instruments that are specifically relevant for the future EarthCARE satellite missions (Illingworth et al. 2015) and Aeolus (ESA 2008) of the European Space Agency. NAWDEX observations, through coordinated flights of multiple aircraft and of aircraft with satellite overpasses, provide data from comparable airborne instruments for the preparation and future validation of these satellite instruments.

HALO was equipped with the HSRL $(532 \mathrm{~nm})$ and the water vapor DIAL WALES, HAMP with a $35.6-\mathrm{GHz}$ cloud radar and microwave radiometers, the cloud spectrometer (specMACS), and the visible to near-infrared SMART instrument (Table 2). The French Falcon was equipped with the radar-lidar (RALI; Protat et al. 2004) payload consisting of the 94-GHz RASTA cloud radar and the UV High Spectral Resolution LNG lidar (Table 2). These aircraft provide the most complete instrumentation package available at the European level to mimic upcoming EarthCARE measurements and thus provide valuable data for preparing the EarthCARE mission and for future validation. Coordinated flights with both aircraft as well as Cloud-Aerosol Lidar and Infrared Pathfinder Satellite Observations (CALIPSO)/CloudSat underpasses during NAWDEX delivered independent measurements for testing EarthCARE level 2 (L2) algorithms at different wavelengths and for performing a first rehearsal of the validation/calibration for EarthCARE.

Figure SBIa illustrates the complementary character of lidar and radar measurements taken during the HALO research flight (RF) on I October 2016. Optically thin ice clouds at cloud top are only visible in the lidar measurements (green-marked curtain), while optically thicker cloud regions are only visible in cloud radar measurements (redmarked curtain).

The DLR Falcon was equipped with a DWL payload consisting of the A2D direct-detection DWL and a 2- $\mu \mathrm{m}$ scanning coherent/heterodyne detection DWL. The A2D is the prototype of the satellite-borne wind lidar instrument on Aeolus and provides range-resolved line-of-sight wind speeds with high data coverage by exploiting both molecular and particulate backscatter return. With a view to the prelaunch activities for the upcoming Aeolus mission, NAWDEX offered the opportunity to extend the A2D dataset and to perform wind measurements in dynamically complex scenes, including strong wind shear and varying cloud conditions, as well as multiple instrument calibrations, which are a prerequisite for accurate wind retrieval. RALI on board the SAFIRE Falcon complemented the A2D instrument with wind measurements in clouds and aerosol-rich layers.

Figure SBIb shows collocated wind observations from the A2D and the 2- $\mu \mathrm{m}$ DWL from a flight of the DLR Falcon east of Iceland on 4 October 2016. The good vertical coverage, limited only by a dense cloud layer, is achieved by combining complementary information from both aerosol backscatter (A2D Mie channel and 2- $\mu \mathrm{m} \mathrm{DWL)} \mathrm{and}$ molecular backscatter (A2D Rayleigh channel).

FIG. SBI. (a) Collocated observations of the vertical cloud structure below HALO, based on lidar (backscatter; along green part of the flight) and radar (radar reflectivity; along red line). The underlying true-color image was acquired by Moderate Resolution Imaging Spectroradiometer (MODIS) Aqua near the time of the flight [Global Imagery Browse Services (GIBS), operated by the NASA/Goddard Space Flight Center (GSFC)/Earth Science Data and Information System]. (b) Collocated wind observations on board the DLR Falcon using the A2D direct-detection wind lidar (along the blue line) and the $2-\mu \mathrm{m}$ coherent DWL (along the red line). The latter is horizontally displaced from the actual flight track for clarity. (Background picture copyright Google 20I7.) 
upon the design of these previous experiments by combining high-resolution remote sensing and in situ instrumentation to provide accurate measurements of atmospheric structures including strong gradients, using multiple aircraft to sample air masses at different stages of the WCB ascent and advection along the tropopause.

To allow these observations to be related to the development of weather forecast errors, NAWDEX employed four research aircraft and ground-based stations spanning the northern part of the North Atlantic with the aim of observing the processes influencing the development of disturbances to the North Atlantic waveguide across the Atlantic. This includes upstream triggering of disturbances on the waveguide by phenomena with strong latent heat release, the continuous effects of clouds and radiation near the tropopause, the dynamical interactions between large-scale disturbances, and the potential impact on weather over Europe from the Mediterranean to Scandinavia.

Airborne platforms and payload. NAWDEX employed four research aircraft: the German High Altitude and Long Range Research Aircraft (HALO) and the Deutsches Zentrum für Luft- und Raumfahrt (DLR) Dassault Falcon 20, the French Service des Avions Français Instrumentés pour la Recherche en Environnement (SAFIRE) Falcon 20, and the British Facility for Airborne Atmospheric Measurements (FAAM) BAe 146. FAAM operated from the United Kingdom and HALO and the two Falcon aircraft from Keflavik, Iceland, in an area covering the North Atlantic, north of $45^{\circ} \mathrm{N}$, and northern and central Europe. The payloads were chosen to observe the required profiles of wind, temperature, moisture, and cloud properties, and in the case of FAAM, in situ cloud microphysics.

The strategy was to deploy HALO with its extended range to observe moisture transport and diabatic processes in weather systems upstream of Iceland that impact the midlatitude waveguide. HALO is a modified Gulfstream G-550 ultra-long-range business jet with a maximum flight range of about 10,000 km and a maximum endurance of $10 \mathrm{~h}$ (Krautstrunk and Giez 2012; Wendisch et al. 2016), which allows for access to remote regions over the central North Atlantic that are not accessible by other European research aircraft. The high ceiling of almost $15 \mathrm{~km}$ in combination with a sophisticated remote sensing payload (see the "Active remote sensing observations for future satellite missions Aeolus and EarthCARE" sidebar and Table 2) allow HALO to fly 
above the main commercial aircraft routes and to probe features of interest from above. The two Falcon aircraft, with a maximum range of $3,000 \mathrm{~km}$, a maximum endurance of about $4 \mathrm{~h}$, and a ceiling up to $12 \mathrm{~km}$, aimed to observe the approaching cyclones and evolving jet streams close to Iceland. The DLR Falcon was equipped with two wind lidar systems and the SAFIRE Falcon with a remote sensing payload for clouds and winds (see the "Active remote sensing observations for future satellite missions Aeolus and EarthCARE" sidebar and Table 2). The FAAM BAe 146, with a maximum endurance of $5 \mathrm{~h}$ and a ceiling of $10 \mathrm{~km}$, was equipped with a range of in situ instrumentation for meteorological, cloud, and chemical measurements together with a downward-pointing aerosol lidar and passive spectral radiometers. Its flights from East Midlands, United Kingdom, were aimed at observing the microphysics and turbulence in WCBs and the structure of the jet stream.

HALO, SAFIRE, and the FAAM aircraft were equipped with dropsonde dispensers to measure air temperature, wind, and humidity profiles. Global NWP centers could access the dropsonde data from HALO and SAFIRE via the Global Telecommunication System in near-real time. The potential for coordinated application of the various instruments on board multiple aircraft was realized through specific instrument-driven science goals (Table 1 and see the "Active remote sensing observations for future satellite missions Aeolus and EarthCARE" sidebar).

TABLE 2. Aircraft and instrumentation for NAWDEX and contribution to research aims (Tablel).

\begin{tabular}{|c|c|c|c|}
\hline Aircraft & Instrument & Measured and derived properties & Aim No. \\
\hline \multirow[t]{7}{*}{ HALO } & \multirow{2}{*}{$\begin{array}{l}\text { HALO Microwave Package (HAMP): } \\
\text { Microwave radiometer with } 26 \text { channels } \\
\text { spanning the frequency range from } 22 \text { to } \\
\text { I } 83 \mathrm{GHz} \text {, and Ka-band }(35.6 \mathrm{GHz}) \text { cloud } \\
\text { radar (Mech et al. } 20 \mathrm{I} 4)\end{array}$} & $\begin{array}{l}\text { Radiometers: Integrated water vapor, } \\
\text { temperature and humidity profiles, liquid } \\
\text { and ice water path }\end{array}$ & \multirow[t]{2}{*}{$2,3,5$} \\
\hline & & $\begin{array}{l}\text { Radar: Profiles of radar reflectivity, } \\
\text { depolarization ratio, vertical velocity }\end{array}$ & \\
\hline & $\begin{array}{l}\text { Water Vapor Differential Absorption Lidar in } \\
\text { Space (WALES): Four-wavelength Differential } \\
\text { Absorption Lidar (DIAL) and High Spectral } \\
\text { Resolution Lidar (HSRL) (Wirth et al. 2009) }\end{array}$ & $\begin{array}{l}\text { Profiles of water vapor, backscatter } \\
\text { coefficient lidar/color ratio, } \\
\text { particle linear depolarization ratio, } \\
\text { particle extinction coefficient }\end{array}$ & $\mathrm{I}, 2,4,5$ \\
\hline & $\begin{array}{l}\text { SMART: Passive cloud spectrometer } \\
\text { (Wendisch et al. 200I; Ehrlich et al. 2008) }\end{array}$ & $\begin{array}{l}\text { Spectral nadir radiance, spectral upward } \\
\text { and downward irradiance ( } 300-2,200 \mathrm{~nm}) \text {, } \\
\text { cloud-top albedo, cloud thermodynamic } \\
\text { phase, cloud optical thickness, effective } \\
\text { radius, cloud cover and statistics }\end{array}$ & $2,4,5$ \\
\hline & $\begin{array}{l}\text { specMACS: Imaging cloud spectrometer } \\
\text { plus } 2 \text { D red-green-blue (RGB) camera } \\
\left( \pm 35^{\circ} \text { field of view) (Ewald et al. } 2016\right)\end{array}$ & $\begin{array}{l}\text { Spectral radiance }(400-2,500 \mathrm{~nm}) \\
\text { push-broom imaging at nadir and } \pm 17^{\circ} \\
\text { across track, cloud thermodynamic phase, } \\
\text { liquid and ice optical thickness, particle } \\
\text { size, cloud cover }\end{array}$ & $2,4,5$ \\
\hline & $\begin{array}{l}\text { Basic HALO Measurements and Sensor } \\
\text { System (Bahamas) }\end{array}$ & $\begin{array}{l}\text { In situ observations of pressure, } \\
\text { temperature, wind, humidity, true air } \\
\text { speed (TAS) aircraft position, attitude, } \\
\text { heading, altitude }\end{array}$ & $3-5$ \\
\hline & Dropsondes Vaisala RD94 & Temperature, humidity, and wind profiles & $1-5$ \\
\hline \multirow[t]{3}{*}{ DLR Falcon } & $\begin{array}{l}\text { Atmospheric Laser Doppler Instrument } \\
\text { (ALADIN) airborne demonstrator (A2D): } \\
\text { Direct-detection DWL (Reitebuch et al. 2009; } \\
\text { Marksteiner et al. 20II) }\end{array}$ & $\begin{array}{l}\text { Profiles of line-of-sight wind speed and } \\
\text { aerosol/cloud layers }\left(20^{\circ} \text { off nadir) }\right.\end{array}$ & 3,5 \\
\hline & $\begin{array}{l}\text { 2- } \mu \text { m scanning coherent/heterodyne } \\
\text { detection DWL (Weissmann et al. 2005; } \\
\text { Witschas et al. 20I7) }\end{array}$ & $\begin{array}{l}\text { Vertical profiles of line-of-sight wind } \\
\text { speed, horizontal wind vectors, and } \\
\text { aerosol/cloud layers }\end{array}$ & 3,5 \\
\hline & Basic in situ measurements & $\begin{array}{l}\text { In situ observations of pressure, } \\
\text { temperature, wind, humidity, TAS aircraft } \\
\text { position, attitude, heading, altitude }\end{array}$ & $3-5$ \\
\hline
\end{tabular}


Table 2 indicates which of the research aims listed in Table 1 are addressed by each instrument.

In parallel with NAWDEX, the National Oceanic and Atmospheric Administration (NOAA) Sensing Hazards with Operational Unmanned Technology (SHOUT) campaign took place in the tropical and subtropical western North Atlantic. SHOUT utilized the unmanned National Aeronautics and Space Administration (NASA) Global Hawk aircraft with a suite of remote sensing platforms and dropsondes to study the impact of the observations on TC forecasts. During the campaign, a tropical storm (TS) moved into the midlatitudes and underwent ET, providing an unprecedented scientific opportunity to observe the interaction of such a system with the jet stream using a combination of upstream flights with the SHOUT Global Hawk and downstream flights with NAWDEX aircraft.

TABLE 2. Continued.

\begin{tabular}{|c|c|c|c|}
\hline Aircraft & Instrument & Measured and derived properties & Aim No. \\
\hline \multirow[t]{5}{*}{ SAFIRE Falcon } & $\begin{array}{l}\text { Radar System Airborne (RASTA): } \\
\text { 95-GHz Doppler cloud radar } \\
\text { (Delanoë et al. 2013) }\end{array}$ & $\begin{array}{l}\text { Doppler velocity and reflectivity from } \\
\text { three antennas (including spectral width), } \\
\text { cloud and precipitation microphysics } \\
\text { (ice and liquid water content), dynamics } \\
\text { (horizontal and vertical wind) }\end{array}$ & $2,3,5$ \\
\hline & $\begin{array}{l}\text { Leandre New Generation (LNG): } \\
\text { HSRL (Bruneau et al. 2015) }\end{array}$ & $\begin{array}{l}\text { Three-wavelength (1064,532, and } 355 \mathrm{~nm}) \\
\text { backscatter lidar with polarization analysis } \\
\text { at } 355 \mathrm{~nm} \text {, high-spectral-resolution } \\
\text { capability including Doppler measurement, } \\
\text { based on a Mach-Zehnder interferometer, } \\
\text { at } 355 \mathrm{~nm} \text {; radiative properties and } \\
\text { dynamics of cloud and aerosol }\end{array}$ & $2,3,5$ \\
\hline & $\begin{array}{l}\text { Conveyable Low-Noise Infrared Radiometer } \\
\text { for Measurements of Atmosphere and Ground } \\
\text { Surface Targets (CLIMAT) (Brogniez et al. 2003) }\end{array}$ & $\begin{array}{l}\text { Radiances measured simultaneously in } \\
\text { three narrowband channels centered at } \\
8.7,10.8 \text {, and } 12.0 \mu \mathrm{m}\end{array}$ & $2,4,5$ \\
\hline & Dropsondes Vaisala RD94 & Temperature, humidity, and wind profiles & $1-5$ \\
\hline & Aircraft in situ measurements & $\begin{array}{l}\text { In situ observations of pressure, } \\
\text { temperature, wind, humidity, TAS aircraft } \\
\text { position, attitude, heading, altitude }\end{array}$ & $3-5$ \\
\hline \multirow[t]{8}{*}{ FAAM BAe I46 } & $\begin{array}{l}\text { In situ temperature, Buck CR-2 and WVSS-2 } \\
\text { hygrometers, two turbulence probes }\end{array}$ & $\begin{array}{l}\text { Temperature, humidity, and wind and } \\
\text { turbulent fluxes }\end{array}$ & 2,3 \\
\hline & $\begin{array}{l}\text { Passive cavity aerosol spectrometer } \\
\text { probe (PCASP), scattering cloud droplet } \\
\text { probe (CDP), cloud imaging probes } \\
\text { (CIP-I5 and CIP-I00) }\end{array}$ & $\begin{array}{l}\text { Cloud particle size spectrum: } \\
2-\mu \mathrm{m}-6-\mathrm{mm} \text { diameter; cloud droplet } \\
\text { spectrum: } 3-50 \mu \mathrm{m}\end{array}$ & 2,5 \\
\hline & Nevzorov hot-wire probe & Ice/liquid water content & 2,5 \\
\hline & $\begin{array}{l}\text { TECO 49C UV analyzer, Aerolaser AL5002, } \\
\text { Los Gatos Fast Greenhouse Gas Analyzer }\end{array}$ & $\mathrm{O}_{3}, \mathrm{CO}, \mathrm{CH}_{4}, \mathrm{CO}_{2}$ & 2 \\
\hline & $\begin{array}{l}\text { Lidar: Downward-pointing Leosphere } \\
\text { ALS450 ( } 355 \mathrm{~nm} \text {, scattering and } \\
\text { depolarization) }\end{array}$ & $\begin{array}{l}\text { Position of different atmospheric layers } \\
\text { below the aircraft (clear air, aerosols, } \\
\text { cloud tops) }\end{array}$ & 2 \\
\hline & $\begin{array}{l}\text { International Sub-Millimetre Airborne } \\
\text { Radiometer (ISMAR) }\end{array}$ & $\begin{array}{l}\text { Passive radiometer with polarization } \\
\text { and multiple channels [I I } 8 \text { and } 243(\mathrm{~V} / \mathrm{H}) \text {, } \\
325,424,448 \text {, and } 664(\mathrm{~V} / \mathrm{H}) \text {, and } 874 \mathrm{GHz} \\
(\mathrm{V} / \mathrm{H})] \text { (IOP I I only) }\end{array}$ & 5 \\
\hline & $\begin{array}{l}\text { Microwave Airborne Radiometer Scanning } \\
\text { System (MARSS) }\end{array}$ & $\begin{array}{l}\text { Scanning microwave radiometer operating } \\
\text { at Advanced Microwave Sounding Unit B } \\
\text { (AMSU-B) channels I6-20 (89-183 GHz) } \\
\text { and pointing both upward and downward } \\
\text { (IOP I I only) }\end{array}$ & 5 \\
\hline & Dropsondes Vaisala RD94 & Temperature, humidity, and wind profiles & $1-5$ \\
\hline
\end{tabular}


Airborne observations. NAWDEX observations took place in the North Atlantic basin between 17 September and 22 October 2016. Figure 2 shows the tracks of the 47 research flights of the four aircraft, together amounting to 205 flight hours. Performing research flights over the North Atlantic is complicated because of the dense transatlantic air traffic. Commercial airliners are tightly staggered along predefined flight routes, the so-called North Atlantic tracks (NATs), between altitudes of 9 and $12 \mathrm{~km}$. Operating research aircraft beneath the NATs offers high flexibility for the flight planning; however, the base height of the NATs is often too low to observe the tropopause and jet-related maximum wind speeds. Furthermore, the location of the NATs changes from day to day, depending on the forecast wind situation. Height changes and the release of dropsondes from high altitudes are not possible in the NAT area. The requirement of air traffic control (ATC) authorities to have detailed flight plans 2-3 days in advance created challenging circumstances in weather situations with reduced predictability (i.e., in situations with large changes between subsequent forecasts). Therefore, NAWDEX combined modern forecasting tools, including ensemble and adjointbased diagnostics, and new visualization techniques to incorporate forecast uncertainty in the planning process (see the "Forecast products for investigating forecast uncertainty" sidebar).

HALO covered large parts of the central and eastern North Atlantic and reached flight distances up to $7150 \mathrm{~km}(\sim 9 \mathrm{~h})$. The flights were performed either at altitudes between 11.5 and $14.2 \mathrm{~km}$ above the NATs for remote sensing observations or at $\sim 8 \mathrm{~km}$ to
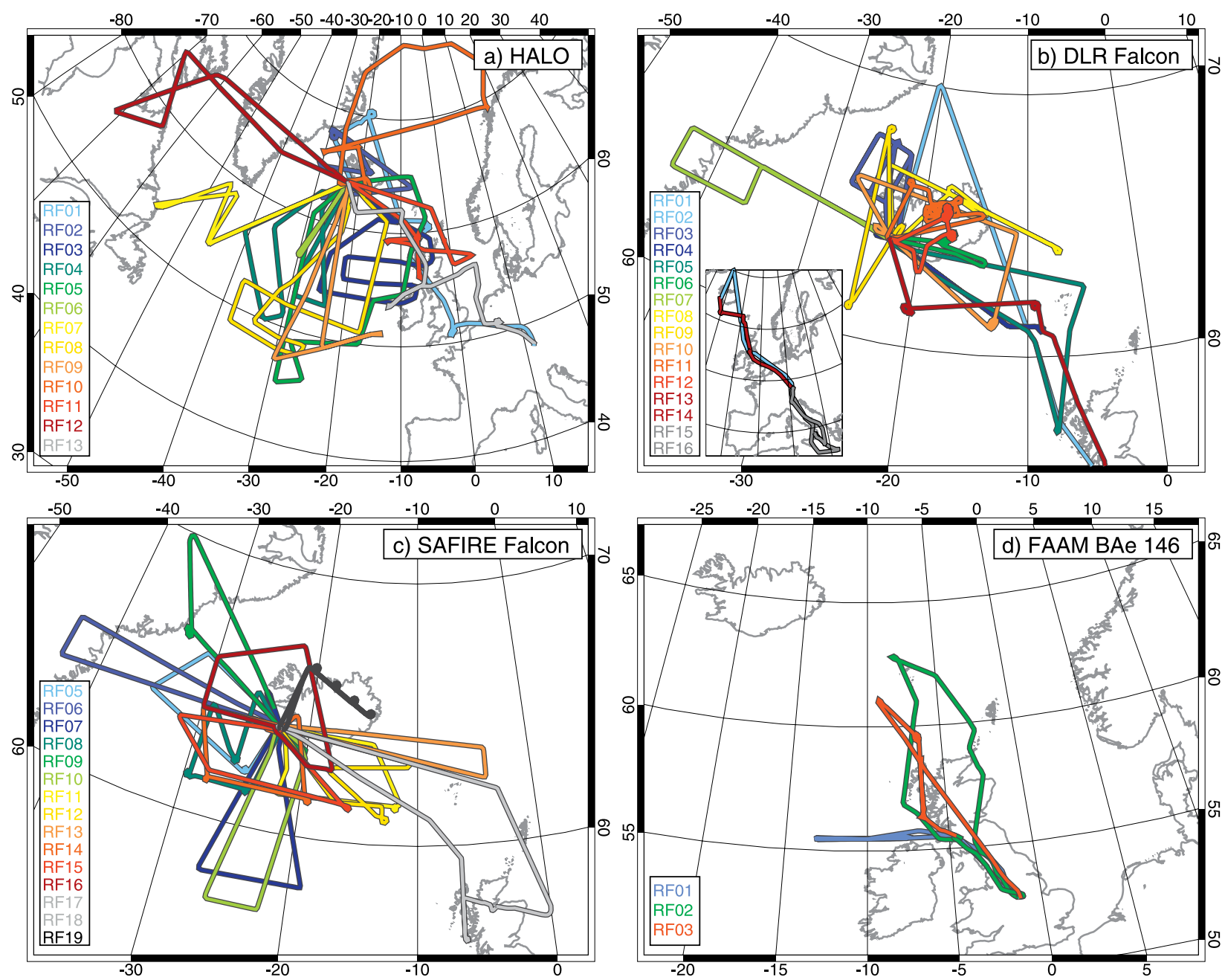

Fig. 2. Tracks of consecutively numbered RFs of (a) HALO (97 flight hours during I3 RFs), (b) DLR Falcon (5I flight hours during 16 RFs), (c) SAFIRE Falcon (42 flight hours during 15 RFs; RF0I-RF04 were made over France just before the campaign to calibrate the instruments), and (d) FAAM BAe 146 ( 15 flight hours during 3 RFs). The inset in (b) shows the DLR Falcon transfer flights and two flights to the Mediterranean at the end of the campaign. 
release dropsondes beneath the NATs. The two Falcon aircraft remained in radar-controlled airspaces near Greenland, Iceland, and the United Kingdom. The FAAM BAe 146 flights were north and west of the United Kingdom. A total of 289 dropsondes were released (Fig. 3a).

The research flights occurred within 13 intensive observation periods (IOPs), which were consecutively numbered and had durations of 1-6 days. Each IOP was associated with a particular weather system development and addressed one or more NAWDEX science objectives (Table 3). For easier communication, the IOPs were given names, which either corresponded to the cyclone naming of the Free University of Berlin or the National Hurricane Center (NHC), or were invented by the NAWDEX team (Table 3). Some IOPs overlap in time when different weather systems were observed simultaneously by the different aircraft.

To exploit instrument synergies and enable direct instrument comparisons, coordinated flights were performed; that is, the same air mass was nearly simultaneously probed by different aircraft on common flight legs. In total, 16 coordinated legs, with a total flight time of $14.5 \mathrm{~h}$ and a distance of about $10,000 \mathrm{~km}$, were achieved. The longest coordinated leg with the SAFIRE Falcon and HALO on 14 October 2016 had a distance of $1,365 \mathrm{~km}$ (1.8 h). On two occasions the coordination involved three aircraft: HALO and the two Falcons flew together for $~ 30 \mathrm{~min}$ $(\sim 300 \mathrm{~km})$ on 9 October between the United Kingdom and Iceland, and on 14 October, FAAM, HALO, and the SAFIRE Falcon had a common leg between the Faroe Islands and Scotland (55 min, $570 \mathrm{~km}$ ).

Ground-based facilities and observations. During several IOPs additional ground-based observations were taken to complement the aircraft operations and to enhance the temporal and spatial coverage of routine observations. In total 589 additional radiosondes from 40 stations in 14 countries were launched (Fig. 3b and Table 4). Of these launches, 253 were achieved through the cooperation of national meteorological agencies in the European Meteorological Services Network (EUMETNET), complemented by additional radiosondes from Iceland, the United Kingdom, France, and Norway. Launches from land stations or commercial ships were requested daily depending on the predicted evolution of weather systems. Furthermore, two additional radiosondes were launched daily during the campaign from six stations in eastern Canada, upstream of the main NAWDEX area (336 in total).

Special ground-based observations were conducted in Iceland, the United Kingdom, and France (Fig. 3b). At Keflavik International Airport, a radiosonde facility
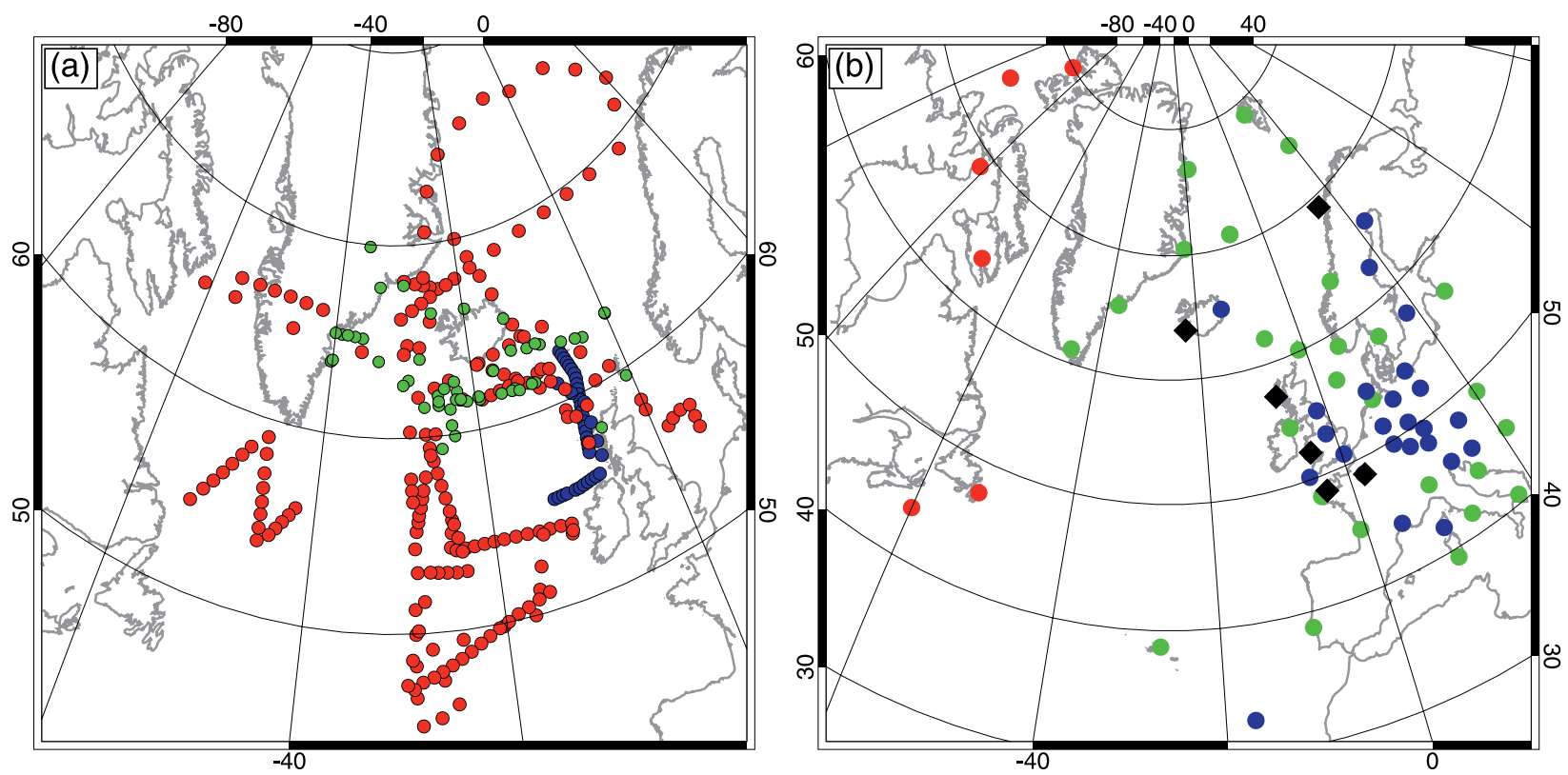

FIG. 3. (a) Dropsondes launched from HALO (red dots; 191 dropsondes), SAFIRE Falcon (green dots; 59 dropsondes), and FAAM BAe 146 (blue dots; 39 dropsondes). (b) Ground-based observation sites during NAWDEX: Canadian radiosonde stations (red dots), European radiosonde stations that performed only operational ascents (blue dots) and those with requested additional radiosonde launches (green dots), and six sites with additional profile observations (black diamonds). 
was set up by DLR to increase the frequency of the operational soundings. In cases of orographically induced gravity waves (GWs), large balloons were launched to reach altitudes up to $42 \mathrm{~km}$. Also in Keflavik, a Doppler cloud radar [the Bistatic Radar System for Atmospheric Studies (BASTA); Delanoë et al. (2016)] allowed several comparisons with its airborne counterpart on board the SAFIRE Falcon during overflights. In the United Kingdom, a mesosphere-stratosphere-troposphere
(MST) radar, Raman lidar, and radiosondes were operated at Capel Dewi in Wales, together with another MST radar wind profiler at South Uist in Scotland. Additionally, the MST radar at Andøya, Norway, measured tropospheric winds upon request. Two observational sites were active in France during the campaign. The site in Lannion (Brittany) operated a wind profiler, the BASTA Doppler cloud radar, and a GPS station. The Site Instrumental de Recherche par

\section{FORECAST PRODUCTS FOR INVESTIGATING FORECAST}

UNCERTAINTY

$N_{n}^{2}$ AWDEX focused on weather phenomena that are poorly represented in NWP, so a strong effort to estimate forecast uncertainty was essential for the planning of the IOPs. Deterministic forecasts from the ECMWF, the Met Office, the Naval Research Laboratory (NRL), Météo-France, the IMO, and the Danish Meteorological Institute (DMI) were available. Additionally, ensemble forecasts from the ECMWF, Met Office [Met Office Global and Regional Ensemble Prediction System (MOGREPS-G)], and Météo-France [Prévision d'Ensemble Action de Recherche Petite Echelle Grande Echelle (ARPEGE), known as the PEARP short-range ensemble] played an essential role.

Each day a standard set of synoptic charts and tailored weather products (e.g., PV on isentropic surfaces and WCB trajectories) were produced using a common map projection and predefined cross sections. Ensemble diagnostics of the mean and spread of several variables, as well as tailored ensemble forecast products for
NAWDEX-relevant features (e.g., WCB and cyclone frequencies, and tropopause height), were created. These forecast products were provided via websites. In addition, an interactive web interface allowed the flight-planning team to compute backward and forward trajectories from planned flight tracks, facilitating the planning of flights to attempt Lagrangian resampling of air masses.

Flight planning typically requires cross-section information, for example, to obtain an accurate picture of tropopause height, winds speeds, and cloud layers and to assess forecast uncertainties along hypothetical flight routes. The NAWDEX community had access to special flight-planning tools that allowed an interactive visualization of forecast products. Central to forecasting and flight-planning operations was the Mission Support System (MSS; Rautenhaus et al. 20I2). In addition, the interactive 3D forecast tool Met.3D (Rautenhaus et al. 2015a) provided specialized forecast products. Two workstations were set up at the operation center in Keflavik to run Met.3D and enable the novel ensemble forecasting workflow described in Rautenhaus et al. (20I5b). Ensemble forecasts by ECMWF could be interactively analyzed in combined 2D-3D depictions. WCB trajectories and derived probabilities of WCB occurrence could be combined with additional forecast information. The ability of Met.3D to interactively navigate the ensemble data proved particularly useful, facilitating analysis of the uncertainty for features such as the predicted tropopause position.

Figure SB2 shows an example of forecast products used for planning the IOP 4 flight. The +60 -h deterministic IFS forecast shows ex-TS Karl as a deep surface cyclone south of Greenland (Fig. SB2a) with cyclonically wrapped PV contours resulting from an advection of low-PV air to upper levels in the outflow of a WCB (not shown). High WCB probabilities with two distinct maxima north and east of Karl indicate that the location of the tropopause and

FIG. SB2. NAWDEX forecast products for I200 UTC 26 Sep 2016 (lead time + 60 h): (a) ECMWF IFS deterministic forecast of PV at $330 \mathrm{~K}$ (color shading) and MSLP (hPa). (b) WCB column probabilities of occurrence (color shading; \%), derived from the ECMWF ensemble (Schäfler et al. 2014; Rautenhaus et al. 20I5b). Black line indicates location of cross section in Met.3D visualizations in (c) and (d). (c) Isosurface of ensemble-mean wind of $60 \mathrm{~m} \mathrm{~s}^{-1}$ (color indicates pressure on isosurface; hPa) and MSLP (black surface contours). The cross section shows ensemble-mean PV (color shading) and potential temperature (black contours). Colored lines represent WCB trajectories of ensemble member 22, starting at 0600 UTC 25 Sep 2016 (colored by pressure). The black vertical poles have been added to aid spatial perception; they are labeled with pressure (hPa). (d) WCB trajectories are as in (c), but from a different viewpoint and combined with a cross section showing 3D WCB probabilities (color shading; \%), ensemble-mean potential temperature (black contours; K), and the 2-PVU isoline (red contour). (e) COAMPS adjoint 48-h forecast moisture sensitivity at 850 hPa [color shading; increments every $\left.0.2 \mathrm{~m}^{2} \mathrm{~s}^{-2}\left(\mathrm{~g} \mathrm{~kg}^{-1}\right)^{-1}\right]$ and $850-\mathrm{hPa}$ geopotential heights (contours every $\left.30 \mathrm{~m}\right)$ valid at I200 UTC 24 Sep (initial forecast time). 
Télédétection Atmosphérique (SIRTA) near Paris, France (Haeffelin et al. 2005), operated radar and lidars, and launched radiosondes.

METEOROLOGICAL CONDITIONS. The fall of 2016 was a favorable period for observing midlatitude weather over the North Atlantic. The average synoptic situation for the campaign period was characterized by an increased frequency of relevant weather systems compared to climatology (Fig. 4). One of the most prominent features was a longlasting blocking high and surface anticyclone covering large parts of Scandinavia (Fig. 4a). Extratropical cyclones occurred more frequently than normal south of Iceland and Greenland (Fig. 4b), in the core area of airborne NAWDEX observations. Consistent with the increased frequency of cyclones relative to climatology, the WCB frequency (Fig. 4c) shows increased
WCB outflow is predicted with high certainty (Fig. SB2b). Images from Met.3D (Figs. SB2c,d) show the relation between the jet stream, WCB, and the tropopause in the ECMWF ensemble mean along cross sections intersecting the waveguide and the WCB east of the surface cyclone. A cross section with ensemble-mean PV (Fig. SB2c) shows a low tropopause north of the jet (depicted by an isosurface of wind speed), whereas a high tropopause appears to the south. This coincides with high probabilities of WCB (Fig. SB2d). WCB trajectories of a selected ensemble member show two distinct branches (Fig. SB2d). One branch wraps cyclonically around the cyclone and features a lower outflow compared to the second branch, which follows anticyclonic pathways at higher elevations, contributing to the elevated WCB probability maximum there. Real-time adjoint products from Coupled Ocean-Atmosphere Mesoscale Prediction System (COAMPS) (Doyle et al. 2014) were used to identify regions of initialcondition sensitivity. At 1200 UTC 24 September, the maximum moisture sensitivity is located in the low to midlevels and is positioned along the eastern portion of TS Karl (Fig. SB2e). The adjoint sensitivity is computed using a kinetic energy response function located in a box $(450 \mathrm{~km} \times 600 \mathrm{~km}$ in the horizontal and extending from the surface to $700 \mathrm{hPa}$ ) centered on the ascending WCB at the 48-h forecast time at 1200 UTC 26 September when the IOP 4 flights were planned. Optimal perturbations derived from the adjoint sensitivity show an increase in wind speeds from 30 to over $45 \mathrm{~m} \mathrm{~s}^{-1}$ in the WCB, highlighting the importance of the midlevel moisture associated with Karl (48 $\mathrm{h}$ prior) for the intensification of the WCB.

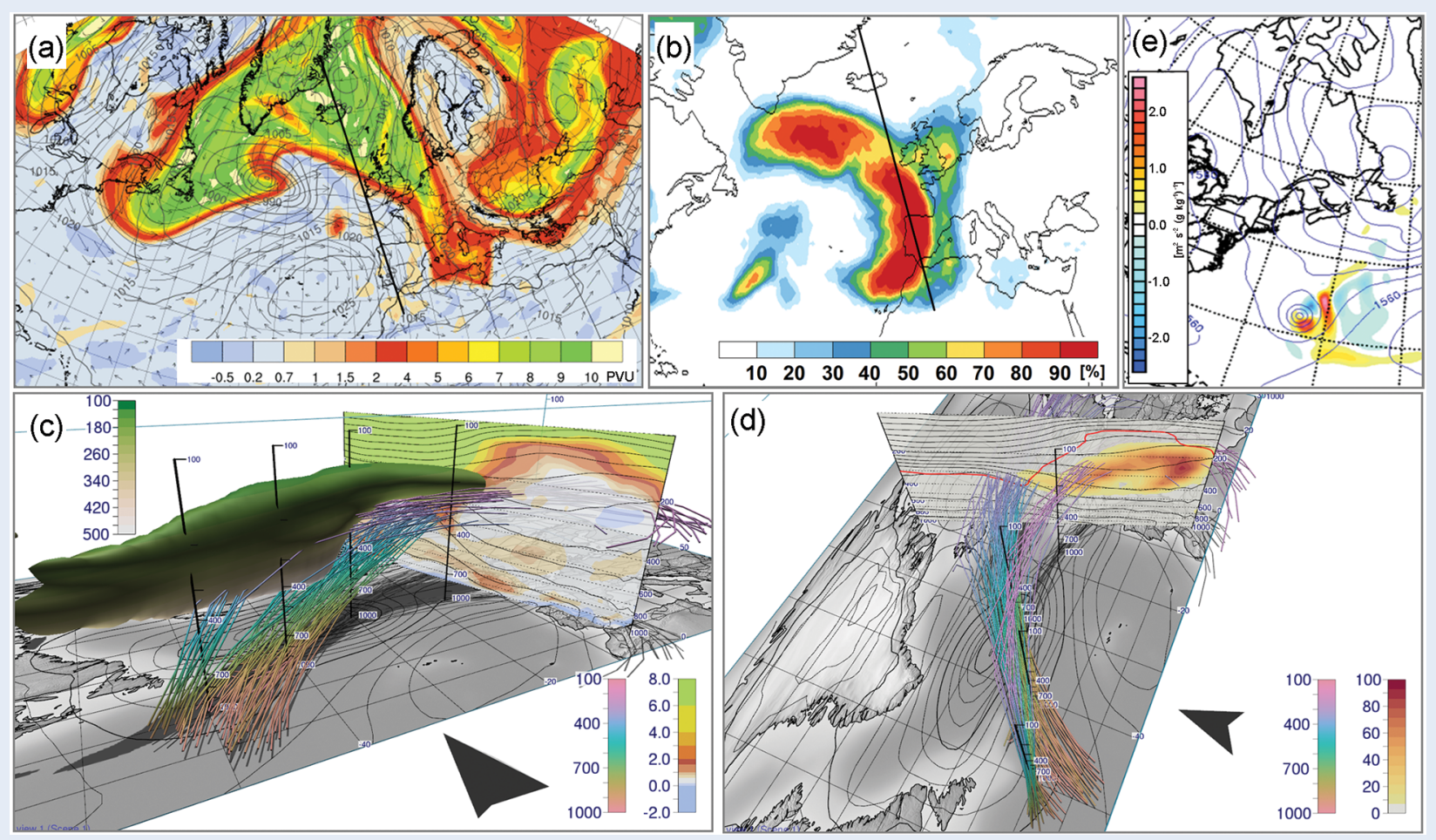




\begin{tabular}{|c|c|c|c|c|c|c|c|c|c|}
\hline IOP & Period & Key weather systems & Date & HALO & $\begin{array}{l}\text { DLR } \\
\text { Falcon }\end{array}$ & $\begin{array}{l}\text { SAFIRE } \\
\text { Falcon }\end{array}$ & $\begin{array}{l}\text { FAAM } \\
\text { BAe I46 }\end{array}$ & $\begin{array}{l}\text { No. of } \\
\text { drops }\end{array}$ & $\begin{array}{l}\text { Aim } \\
\text { No. }\end{array}$ \\
\hline 1 & 16-17 Sep & $\begin{array}{l}\text { Outflow of ex-TC lan, } \\
\text { low-predictability case }\end{array}$ & $17 \mathrm{Sep}$ & RFOI & RF0I, RF02 & & & 10 & $2-5$ \\
\hline 2 & $21-22$ Sep & $\begin{array}{l}\text { WCB ascent and outflow of } \\
\text { extratropical Cyclone Ursula }\end{array}$ & $21 \mathrm{Sep}$ & RF02 & RF03 & & & 14 & $2-5$ \\
\hline 3 & $23-25 \mathrm{Sep}$ & $\begin{array}{c}\text { WCB ascent of extratropical } \\
\text { Cyclone Vladiana }\end{array}$ & $23 \mathrm{Sep}$ & RF03 & RF04 & & $\begin{array}{l}\text { RF0I } \\
\text { (B980) }\end{array}$ & 32 & $\mathrm{I}-5$ \\
\hline \multirow[b]{2}{*}{4} & \multirow[b]{2}{*}{ 22-28 Sep } & \multirow{2}{*}{$\begin{array}{l}\text { Reintensification phase of } \\
\text { ex-TS Karl and jet streak } \\
\text { forming downstream }\end{array}$} & $26 \mathrm{Sep}$ & RF04 & & & & 25 & \multirow[b]{2}{*}{$2-5$} \\
\hline & & & $27 \mathrm{Sep}$ & RF05 & RF05 & & $\begin{array}{l}\text { RF02 } \\
\text { (B98I) }\end{array}$ & 22 & \\
\hline 5 & 26-29 Sep & $\begin{array}{c}\text { Strong water vapor transport of } \\
\text { extratropical Cyclone Walpurga } \\
\text { leading } \\
\text { to HIW in Scandinavia }\end{array}$ & $27 \mathrm{Sep}$ & RF05 & & & & 20 & $\mathrm{I}, 3,4$ \\
\hline \multirow{2}{*}{6} & \multirow{2}{*}{$\mathrm{I}-5 \mathrm{Oct}$} & \multirow{2}{*}{$\begin{array}{l}\text { Stalactite cyclone and low } \\
\text { predictability over Europe }\end{array}$} & I Oct & RF06 & & RF05 & & 3 & \multirow{2}{*}{$2-5$} \\
\hline & & & 2 Oct & & RF07 & RF06, RF07 & & 9 & \\
\hline \multirow[b]{2}{*}{7} & \multirow{2}{*}{$4-5$ Oct } & \multirow{2}{*}{$\begin{array}{c}\text { Strong extratropical cyclone } \\
\text { originating as frontal wave } \\
\text { near Newfoundland }\end{array}$} & $4 \mathrm{Oct}$ & & RF08, RF09 & RF08 & & 5 & \multirow{2}{*}{$2-4$} \\
\hline & & & $5 \mathrm{Oct}$ & & & RF09 & & 4 & \\
\hline \multirow{4}{*}{8} & \multirow{4}{*}{ 6-9 Oct } & \multirow{4}{*}{$\begin{array}{l}\text { TPV near Newfoundland } \\
\text { and downstream-forming } \\
\text { cyclone }\end{array}$} & 6 Oct & RF07 & & & & 20 & \multirow{4}{*}{4,5} \\
\hline & & & 7 Oct & & & RFIO & & 7 & \\
\hline & & & 9 Oct & RF08 & RFIO & RFII, RFI2 & & 9 & \\
\hline & & & $10 \mathrm{Oct}$ & & & RFI3 & & 6 & \\
\hline \multirow[b]{2}{*}{9} & \multirow[b]{2}{*}{$9-14$ Oct } & \multirow{2}{*}{$\begin{array}{l}\text { PV cutoff Cyclone Sanchez } \\
\text { and downstream impact } \\
\text { over the Mediterranean }\end{array}$} & 9 Oct & RF08 & & & & & \multirow{2}{*}{$2-5$} \\
\hline & & & $10 \mathrm{Oct}$ & RF09 & & & & 20 & \\
\hline \multirow{4}{*}{10} & \multirow{4}{*}{$12-15$ Oct } & \multirow{4}{*}{$\begin{array}{l}\text { Formation and extension } \\
\text { of tropopause ridge Thor } \\
\text { and the Scandinavian } \\
\text { anticyclone }\end{array}$} & $11 \mathrm{Oct}$ & & & RFI4 & & 4 & \multirow{4}{*}{$3-5$} \\
\hline & & & $12 \mathrm{Oct}$ & & & RFI5 & & 8 & \\
\hline & & & $13 \mathrm{Oct}$ & RFIO & & RFI6 & & 26 & \\
\hline & & & $15 \mathrm{Oct}$ & RFI2 & & & & 12 & \\
\hline 11 & $14 \mathrm{Oct}$ & $\begin{array}{l}\text { Radar and lidar mission for } \\
\text { instrument comparisons and } \\
\text { satellite underflights }\end{array}$ & $14 \mathrm{Oct}$ & RFII & & RFI7, RFI8 & $\begin{array}{l}\text { RF03 } \\
\text { (B984) }\end{array}$ & 15 & 5 \\
\hline 12 & $15 \mathrm{Oct}$ & TPV over Baffin Island & $15 \mathrm{Oct}$ & RFI2 & & & & & 4,5 \\
\hline 13 & $18 \mathrm{Oct}$ & $\begin{array}{l}\text { PV streamer over the } \\
\text { United Kingdom }\end{array}$ & $18 \mathrm{Oct}$ & RFI3 & RFI3, RFI4 & & & 16 & 2,3 \\
\hline & & \multirow{4}{*}{$\begin{array}{l}\text { Instrument and } \\
\text { calibration flights }\end{array}$} & $28 \mathrm{Sep}$ & & RF06 & & & & \multirow{4}{*}{5} \\
\hline & & & $15 \mathrm{Oct}$ & & RFII, RFI2 & & & & \\
\hline & & & $16 \mathrm{Oct}$ & & & RFI9 & & 2 & \\
\hline & & & $22 \mathrm{Oct}$ & & RFI5, RFI6 & & & & \\
\hline
\end{tabular}

activity over large parts of the North Atlantic. During the campaign, a succession of events with poleward transport of warm air and ascent of low-PV air into the upper troposphere was observed that appeared to strengthen the downstream anticyclonic anomaly.
Most midlatitude cyclones (Fig. 4d) approached Iceland from the southwest, which was favorable for reaching them with Falcon flights from Keflavik. Only a small fraction of the extratropical cyclones moved into central and northern Europe. Six TSs 


\begin{tabular}{|c|c|c|}
\hline IOP & Period & Additional observations \\
\hline I & 16-17 Sep & $\begin{array}{l}\text { Radiosondes from the United Kingdom, Tórshavn, Faroe Islands, and Iceland for a temporal } \\
\text { sequence of the arrival of outflow of ex-TC lan as it extends northeastward }\end{array}$ \\
\hline 2 & $21-22$ Sep & $\begin{array}{l}\text { Radiosondes from the United Kingdom, Iceland, and eastern Greenland for a time series during } \\
\text { the arrival and passage of Cyclone Ursula }\end{array}$ \\
\hline 3 & $23-25 \mathrm{Sep}$ & $\begin{array}{l}\text { Radiosondes from the northern United Kingdom to observe rapidly intensifying frontal Cyclone } \\
\text { Vladiana with strong WCB and ridge building }\end{array}$ \\
\hline 4 & 26-28 Sep & $\begin{array}{l}\text { Radiosondes around the northern North Atlantic and Scandinavia to observe the structure } \\
\text { and evolution of ex-TS Karl and to observe GWs above Iceland at the jet stream; jet-streak } \\
\text { maximum passes directly above MST radar wind profiler at South Uist, Scotland }\end{array}$ \\
\hline 5 & 27-29 Sep & $\begin{array}{l}\text { Radiosondes in the United Kingdom and southern Scandinavia to observe the strong water } \\
\text { vapor transport and related HIW; passage of jet stream over Capel Dewi }\end{array}$ \\
\hline 6 & I-5 Oct & $\begin{array}{l}\text { Radiosondes northwest of Iceland to observe ridge building in relation to the stalactite cyclone; } \\
\text { radiosondes over southern Europe to observe a cutoff downstream; radiosondes at Iceland to } \\
\text { observe GWs in the stratosphere }\end{array}$ \\
\hline 8 & 6-9 Oct & $\begin{array}{l}\text { Radiosondes over Iceland and eastern Greenland to observe WCB ascent and cyclone structure; } \\
\text { observation of orographic GWs above Iceland }\end{array}$ \\
\hline 9 & $10-14$ Oct & $\begin{array}{l}\text { Radiosondes from the western Mediterranean, at Capel Dewi, and at SIRTA to observe cutoff } \\
\text { Sanchez and related HIW; passage of outflow from Sanchez over MST radar at Capel Dewi; } \\
\text { radiosondes above Iceland to observe strong GW activity in the stratosphere }\end{array}$ \\
\hline 8,10 & $10-150 c t$ & $\begin{array}{l}\text { Radiosondes over the North Atlantic to obtain a time series of the vertical structure of ridge } \\
\text { Thor; MST radar wind observations at Andøya, Norway }\end{array}$ \\
\hline 11 & $15-16$ Oct & Radiosondes at SIRTA to observe the downstream impact \\
\hline
\end{tabular}

occurred during NAWDEX. Ian (12-16 September), Julia (13-16 September), Karl (14-25 September), and Lisa (19-25 September) did not exceed TS strength, while Matthew (29 September-9 October) and Nicole (4-18 October) were classified as major hurricanes. Ian, Karl, and Nicole underwent ET and moved far into the midlatitudes. TPVs originating over the Canadian polar region were observed twice when they moved southward over the Davis Strait and interacted with the midlatitude waveguide.

North Atlantic weather regimes during NAWDEX show Scandinavian blocking to be the dominant regime (blue line in Fig. 5a), corresponding to the anomalous anticyclone activity over northern Scandinavia (Fig. 4a). In late September the block decayed and a short period with a positive North Atlantic Oscillation (NAO) prevailed before the Scandinavian blocking pattern was again established.

A broad measure of forecast quality during NAWDEX is provided by the anomaly correlation coefficient (ACC) of the midtropospheric geopotential height pattern over the eastern North Atlantic, as predicted by the European Centre for MediumRange Weather Forecasts (ECMWF) Integrated Forecast System (IFS) in fall 2016 (Fig. 5b). Periods of increased 120-h forecast errors and high spread in the ensemble forecasts are evident, and four of these periods were directly relevant to NAWDEX. Three periods of reduced forecast skill (23-27 September, 29 September-3 October, and 5-10 October) occurred during NAWDEX and two periods among the four were accompanied by a weather regime transition (Fig. 5a). Forecast uncertainty was high on 26 September during the onset of a positive NAO phase, and on 1 October during the return to the Scandinavian blocking regime. High uncertainty also occurred prior to the campaign, for forecasts initialized between 10 and 14 September, again covering a regime transition to Scandinavian blocking. This period affected NAWDEX as it complicated the planning of the transfer flight to Keflavik (IOP 1) 5 days later.

The progression of weather systems across the North Atlantic during NAWDEX can be conveniently described as a storyline characterized by upstream triggers, their dynamic interaction with the jet stream, subsequent development of disturbances, and downstream weather impacts over Europe. Three such sequences occurred completely within the NAWDEX period, and their timespan is indicated by dark gray shading in Fig. 5. In each case, low predictability was found in 5-day forecasts for the eastern North Atlantic initialized within the 
trigger stage (marked by a drop in forecast skill in Fig. 5b), while the final impact stage was associated with significant changes in the weather over Europe at the verification time 5 days later. The snapshots for each sequence in Fig. 6 show that the interaction of the trigger disturbance with the waveguide featured intensification of a surface cyclone, with a diabatic contribution consistent with the first three regions identified in the conceptual model presented in Fig. 1. However, the subsequent development and impact stages differed markedly, with the pattern of low PV in the downstream ridge affecting weather even farther downstream than suggested by region 4 in Fig. 1. The temporal continuity between the snapshots in Fig. 6 is shown by labeling several coherent long-lived features (identified in the caption). Prominent ridges (R1-R9) along the North Atlantic waveguide are identified as northward excursions of the jet stream (and the PV gradient). Since each ridge is characterized by low-PV air, the associated flow tends to be anticyclonic.

Sequence A is triggered by TS Karl leaving the subtropics and moving northward into the midlatitudes (Fig. 6, sequence A1). Large ensemble
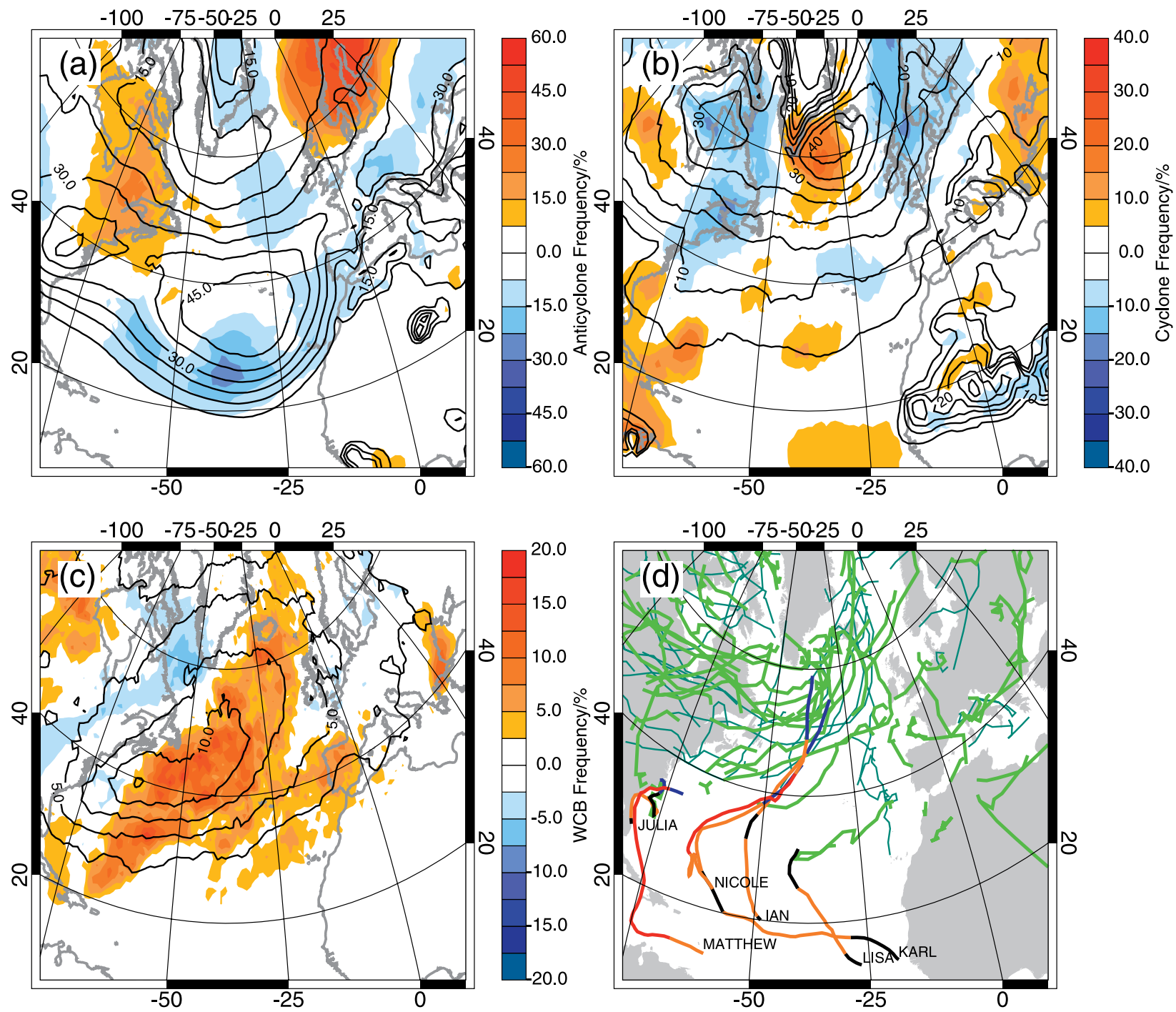

FIG. 4. (a)-(c) Synoptic-scale conditions during NAWDEX. All panels are based on ERA-Interim data (I979-2016), with color shading showing frequency deviations (\%) during the campaign period in 2016 from the mid-September to mid-October climatology for (a) surface anticyclones, (b) surface cyclones, and (c) WCB. The tracking method is explained in Sprenger et al. (20I7). Black contours show the ERA-Interim 37-yr climatological mean. (d) Best-track data [from the NHC "best track" hurricane database (HURDAT2)] from six TCs (red sections classified as hurricane, orange as TS, and blue as extratropical storm), and cyclone tracks during the NAWDEX period (light green lines) and before and after the campaign period (dark green lines). 
spread and changes between consecutive forecast runs showed that the subsequent evolution was very sensitive to uncertainties in the location and timing of the interaction of Karl with ridge R2, the trough upstream, and the associated weak surface cyclone (not shown). The interaction that took place was a merging of Karl with a low-level cyclone, leading to rapid reintensification and the formation of a cyclonic hook at tropopause level separating ridge $\mathrm{R} 2$ from the new ridge $\mathrm{R} 3$ (Fig. 6, sequence A2). The ridge building is intensified by diabatically produced low $\mathrm{PV}$ in the WCB outflow. Hence, in the subsequent development, the jet stream is unusually strong on its southern flank, forming a jet streak that propagates ahead from Karl, reaching Scotland the following day (Fig. 6, sequence A3). The impact on European weather occurs through the formation of a new cyclone, Walpurga (W in Fig. 6, sequence A4), which develops to the west of ridge $\mathrm{R} 3$, helping to amplify it. Moisture-laden air on the western flank of ridge R3 is drawn around the subtropical high. During IOP 5, HALO observed the moist boundary layer in this atmospheric river-type flow that extends to Norway, where it causes heavy, persistent rainfall, similar to the case studied in Sodemann and Stohl (2013).

Sequence B begins as sequence A ends, in a southwesterly flow situation with a long PV streamer that formed through the merger of the trough west of R3 and the large cutoff feature C (Fig. 6, sequences A3 and A4). The trigger for this sequence appears to follow from the vortex rollup of the streamer through shear instability, resulting in a new cutoff over Newfoundland (V in Fig. 6, sequence B1), which then interacts and merges with a large-scale trough west of R5 advancing rapidly from the northwest. Note that ridge R5 and its upstream trough wrap up cyclonically during the development so that the trough catches up with the cutoff to the south of R5. The tropopause was very low just in the very center of this system, which therefore has been named the stalactite cyclone (St in Fig. 6, sequence B2). In the development stage, a second cyclone
(F in Fig. 6, sequence B3) intensified rapidly between ridge R6 and the trough to its west. The polewardmoving air in R6 crossed Iceland and reinforced the anticyclonic anomaly formed by ridge $\mathrm{R} 5$ of the stalactite cyclone. The impact of the sequence comes not as a classical severe weather event, but through the establishment of a strong blocking anticyclone over northern Europe, which persisted for the next 2 weeks.

Sequence $\mathrm{C}$ begins with two upstream triggers. A TPV originating in the Canadian Arctic is carried rapidly southeastward on the poleward flank of

AUGUST | SEPTEMBER | OCTOBER | NOVEMBER (a) $1^{0}, \lambda^{8} 1^{8} \eta^{2} \eta^{6} 3^{0} 0^{3} 0^{1} \lambda^{1}, 1^{5} \lambda^{9} \eta^{3} \eta^{1} 0^{1} 0^{5} 0^{9} \lambda^{3} \lambda^{1} \eta^{1} \eta^{5} \eta^{9} 0^{2} 0^{6}, 0, \lambda^{2} 1^{8}$

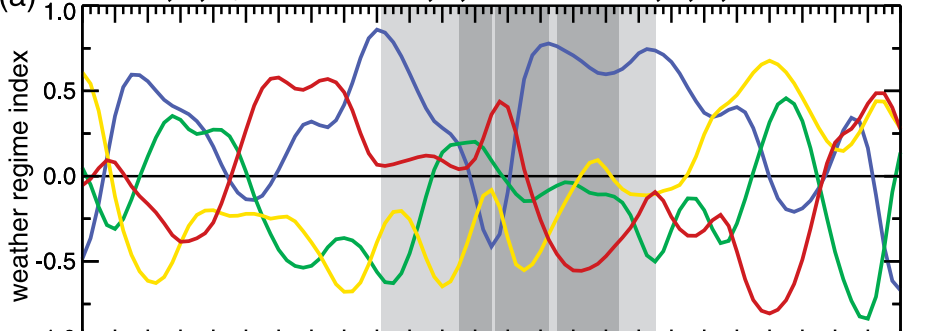

(b)

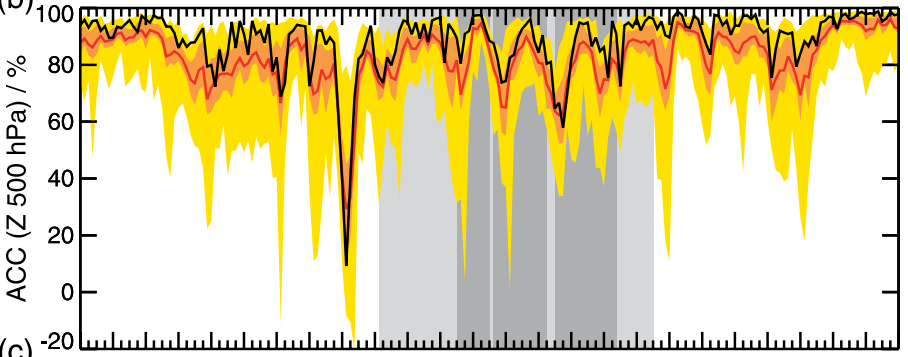

(c)

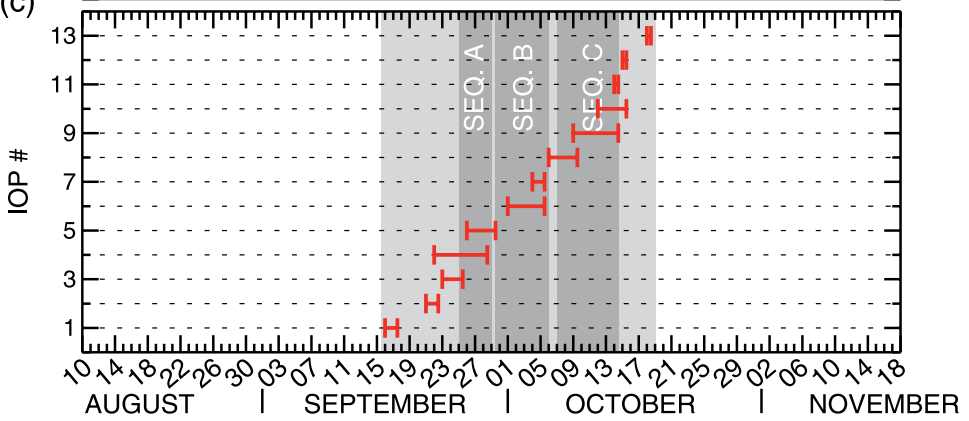

FIG. 5. (a) Weather regime indices following the definition of Michel and Rivière (20II): Scandinavian blocking (blue line), positive NAO (red line), negative NAO (green line), and Atlantic ridge (yellow line), identified with a $k$-means clustering approach (Michelangeli et al. 1995). (b) Time series of the ECMWF IFS ACC for geopotential height at $500 \mathrm{hPa}$ over an area from $35^{\circ}$ to $75^{\circ} \mathrm{N}$ and from $60^{\circ} \mathrm{W}$ to $0^{\circ}$ for a forecast lead time of $+120 \mathrm{~h}$ (shown at the initial time of the forecast): IFS deterministic forecast (black line), ensemble mean (red line), $50 \%$ of the ensemble members (orange area), and all members (yellow area). (c) NAWDEX IOPs as indicated in Table 3 (red bars). Light gray box depicts the NAWDEX campaign period and the dark gray boxes mark the durations of weather sequences, as shown in Fig. 6. 
the jet stream ( $\mathrm{T}$ in Fig. 6, sequences $\mathrm{B} 4$ and $\mathrm{C} 1$ ). It is hypothesized that the TPV locally enhanced the cyclonic circulation about the tip of the large-scale trough ( $\mathrm{T}$ in Fig. 6, sequence $\mathrm{C} 1$ ), which eventually wrapped cyclonically over Iceland (Fig. 6, sequence C2). At the same time, the remnants of cutoff $\mathrm{C}$ appear to be associated with the emergence of a small surface cyclone, which has been named Sanchez ( $\mathrm{S}$ in Fig. 6, sequence C1). The European dipole block (cf. Rex 1950) is well established at this time so that the ridge R8 and the cyclonic PV anomaly over Iceland are held stationary and a PV filament forms in the deformation region on their western side. The filament is unstable and experiences vortex rollup, forming three tropopause-level cyclonic vortices. The key interaction in this sequence occurs as the low-level
Cyclone Sanchez passes the southernmost cutoff, but then phase locks with the central cutoff, resulting in baroclinic intensification ( $\mathrm{S}$ in Fig. 6, sequence $\mathrm{C} 2$ ). As the sequence develops, the resulting cutoff cyclone progresses slowly eastward (Fig. 6, sequence C3) and is responsible for some of the most dramatic high-impact weather during NAWDEX, with heavy precipitation and flooding across southern France and northwestern Italy in the southerly flow ahead of it (Fig. 6, sequence C4). But this HIW is not the only significant outcome of sequence C. Returning to stage $\mathrm{C} 2$, ridges $\mathrm{R} 8$ and $\mathrm{R} 9$ are similar in their horizontal extent, but the tropopause is much higher above R9 than R8 (not shown) with the result that the anticyclonic circulation induced by $\mathrm{R} 9$ is stronger and R8 is stretched out meridionally between R6 and
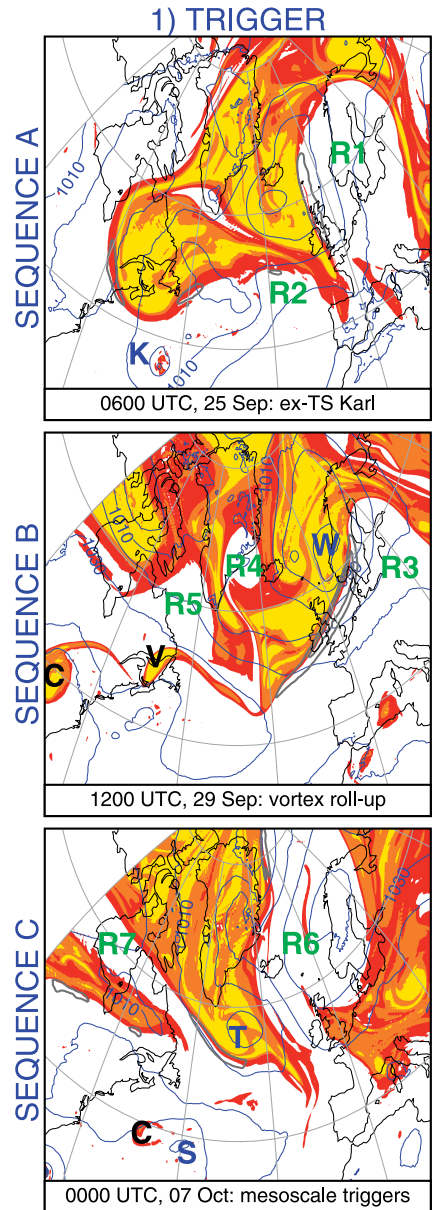

2) INTERACTION
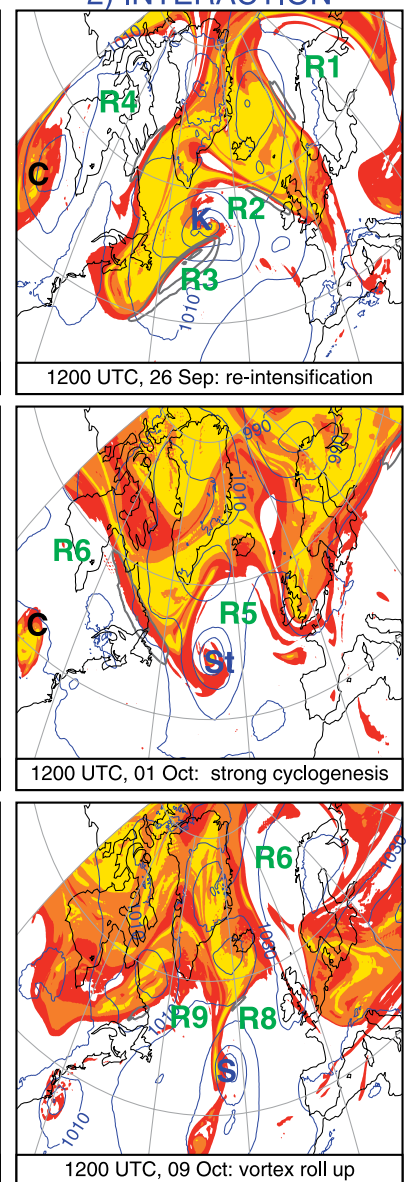

3) DEVELOPMENT
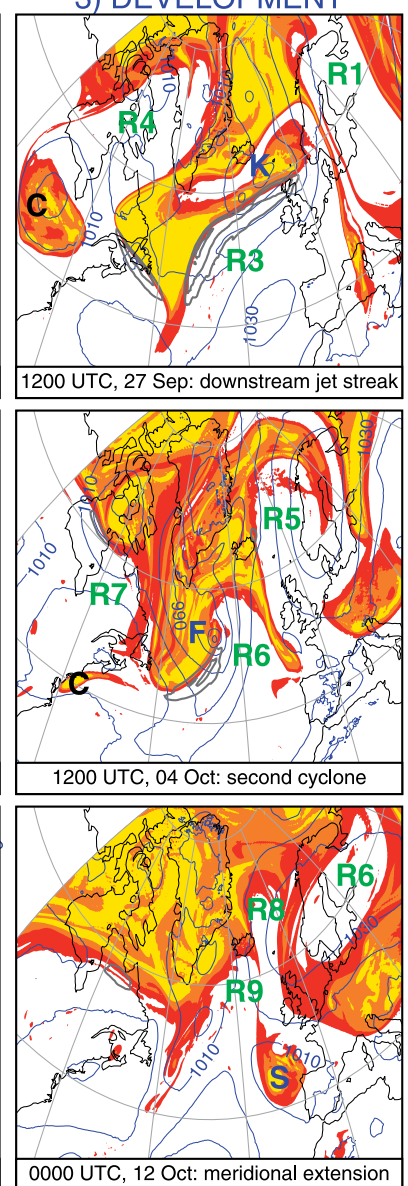
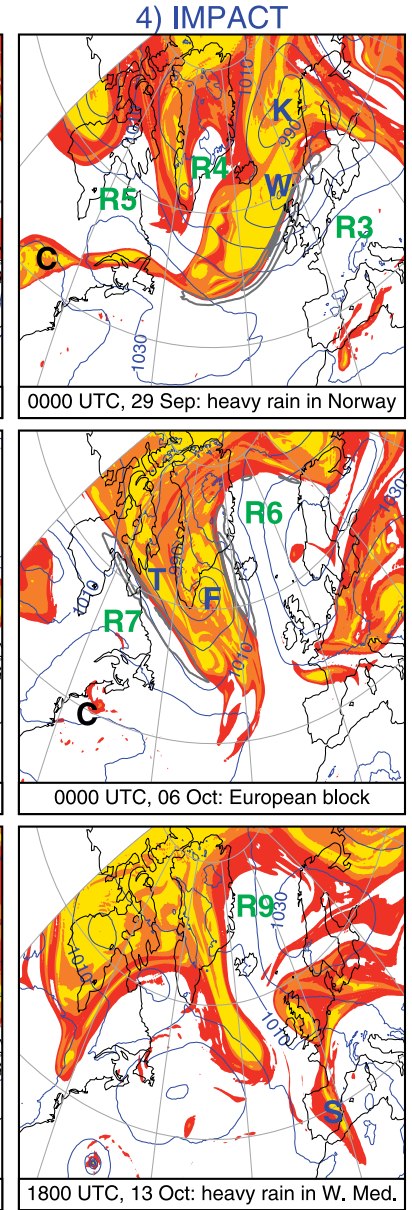

FIG. 6. Three sequences that illustrate the NAWDEX storyline of (left to right) trigger, interaction, development, and HIW in Europe (based on ECMWF IFS operational analyses). All panels display PV at $325 \mathrm{~K}$ (PV < 2 PVU in white, $2 \geq \mathrm{PV}<5$ PVU in red, $5 \geq \mathrm{PV}<8$ PVU in orange, PV $\geq 8$ PVU in yellow), wind speed (gray contours; 60, 70, and $80 \mathrm{~m} \mathrm{~s}^{-1}$ ), and mean sea level pressure (MSLP; blue contours; interval: $10 \mathrm{hPa}$ ). Some long-lived, coherent features are labeled to enable links from one frame to the next: $K$ refers to TS Karl; W, F, S, and St mark midlatitude cyclones observed by NAWDEX; C labels a tropopause-level cutoff that persists for 10 days; RI-R9 refer to the prominent ridges along the North Atlantic waveguide, identified as northward excursions of the jet stream and the isentropic PV gradient; and T marks a TPV. 
R9 (Fig. 6, sequence C3). As NAWDEX draws to a close, the ridge $\mathrm{R} 9$ extends rapidly into the Arctic, reinforcing the block and forming a PV anomaly in the shape of the Icelandic character $\mathrm{P}$ (the first letter of Por, pronounced Thor, the ancient Norse god of HIW).

It is important to note that the large-amplitude ridge building leading to the Thor block is not R8, which developed as part of the interaction phase of sequence $\mathrm{C}$, but rather $\mathrm{R} 9$, which is associated with a second cyclone that develops to the west (and which may play a role in the cutoff of Sanchez). Indeed for all three sequences, the development stage leading to weather impacts over Europe appears to be associated with a second cyclone that forms in an environment modified by the interaction of the trigger disturbance with the midlatitude flow, and whose development is difficult to project because of the low predictability of the environment.

HIGHLIGHTS OF NAWDEX. Observations in NAWDEX were organized into IOPs that focused on key weather systems involved in the longer sequences (Table 5). Several of these IOPs are unprecedented in terms of the phenomena that were sampled or the comprehensive coverage and multifaceted nature of the measurements. While the analysis of the data is just beginning, a first impression of the results can be obtained from four highlights that illustrate the unique sets of multiplatform and multi-instrument observations that were obtained.
Extratropical transition of TS Karl. The evolution of TS Karl is the central feature of sequence A discussed above and IOP 4. It was the first extratropical transition sequence that has been observed with research aircraft through all stages of its development, including TS status, ET, reintensification with impacts on jet-stream strength, moisture transport, and downstream HIW (Table 5). By flying over the TS and its northwestern flank twice, the SHOUT Global Hawk observed the development stage that occurred far south of the midlatitude jet stream on 22-23 September (Fig. 7a) and the ET phase on 24-25 September (Fig. 7b). On 26 September, HALO observed the interaction with the waveguide and reintensification phase of the storm by flying over the cyclone center (Fig. 7c), WCB ascent, the low-valued PV air in the WCB outflow, and the dry intrusion (not shown). When Karl moved rapidly toward Scotland, decaying in strong horizontal shear on 27 September, IOP 5 focused on the intense jet streak at the tropopause level and the strong moisture transport along the equatorward side of the jet with a combination of HALO, FAAM, and DLR Falcon flights (Fig. 7d).

IOP 4 will contribute to answering several of the posed research questions (see Tables 1 and 3). The large number of dropsonde and special radiosonde measurements that were assimilated into operational forecasts in real time will provide a basis for observational impact and predictability studies. Detailed airborne remote sensing observations will

\section{TABLE 5. NAWDEX observational highlights.}

\begin{tabular}{|c|c|c|}
\hline IOP & Period & Specific aspects of the observations \\
\hline 3 & 23-25 Sep & $\begin{array}{l}\text { Coordinated flights to observe the cloud structure and cloud physics in the WCB ascent } \\
\text { related to Cyclone Vladiana and the interaction of the WCB outflow with the jet stream }\end{array}$ \\
\hline 4 & 22-28 Sep & $\begin{array}{l}\text { First-ever observations of a TS from tropical phase and ET (SHOUT observations) through } \\
\text { midlatitude reintensification, jet-streak formation, ridge enhancement, and HIW over } \\
\text { Scandinavia (NAWDEX observations) }\end{array}$ \\
\hline 5 & 26-29 Sep & $\begin{array}{l}\text { Large-scale strong moisture transport in an atmospheric river-type flow upstream of Cyclone } \\
\text { Walpurga causing HIW over Scandinavia }\end{array}$ \\
\hline 6 & $1-5$ Oct & $\begin{array}{l}\text { Lowest-predictability case with observations of the WCB ascent and outflow of the stalactite } \\
\text { cyclone and the subsequent influence on the onset of the European block }\end{array}$ \\
\hline 8,12 & 26-29 Sep, 15 Oct & $\begin{array}{l}\text { First-ever airborne observations of temperature, wind, and moisture structure of two TPV } \\
\text { events in a phase when they interacted with the midlatitude waveguide }\end{array}$ \\
\hline 9 & $9-14$ Oct & $\begin{array}{l}\text { Rollup of the positive PV filament giving rise to Mesocyclone Sanchez connected to HIW in } \\
\text { France and Italy }\end{array}$ \\
\hline 10 & $12-15 \mathrm{Oct}$ & $\begin{array}{l}\text { Low-PV ridge builds and extends into the Arctic, reinforcing the anticyclonic part of the block; } \\
\text { profile observations characterizing the low-PV anomaly structure }\end{array}$ \\
\hline II & 14 Oct & $\begin{array}{l}\text { Coordination of three aircraft and joint underflight of the CALIPSO/CloudSat satellite path to } \\
\text { exploit instrument synergies of radar, lidar, and radiometer instruments }\end{array}$ \\
\hline
\end{tabular}


allow examination of the role of diabatic processes and their representation in numerical models. Both the synergies of the instruments and the stormfollowing observational strategy give unprecedented information about this intense and long-lived cyclone and a unique opportunity to analyze forecast error growth due to in situ processes versus downstream propagation.

Cloud physics in a WCB. IOP 3 focused on observing the vertical cloud structure and cloud microphysical processes in a WCB that was related to the Midlatitude Cyclone Vladiana south of Iceland and west of Scotland on 23 September 2016 (Fig. 8a and Table 5). The WCB transported moist air northeastward just west of the United Kingdom, as indicated by the low-valued PV air in the upper troposphere (Fig. 8a).

HALO first stayed beneath the NATs at altitudes of $\sim 8 \mathrm{~km}$ on the way to the southwesternmost point of the flight (white circle) to begin the first of three sections across the WCB. On this leg to Ireland, 12 dropsondes were released before HALO climbed to $\sim 13 \mathrm{~km}$ in Irish airspace. Over northern Ireland, HALO and FAAM joined to perform coordinated remote sensing and in situ observations of the WCB. HALO measured the WCB by remote sensing from above while FAAM performed four in situ legs at different altitudes to measure cloud microphysical parameters inside the WCB. After the coordinated leg, HALO crossed the WCB a third time and observed the outflow of the WCB between Scotland and Iceland.

Figure 8 focuses on the first and second crossings of the WCB. The water vapor lidar measured water vapor profiles throughout the troposphere and lower stratosphere in the absence of clouds (Fig. 8b). On the western side of the cross sections, where HALO was located along the stratospheric side of the waveguide, the postfrontal troposphere was cloud free except for boundary layer clouds reaching up to $2 \mathrm{~km}$. The water vapor shows high variability, which portrays the dynamically modulated transport of moisture
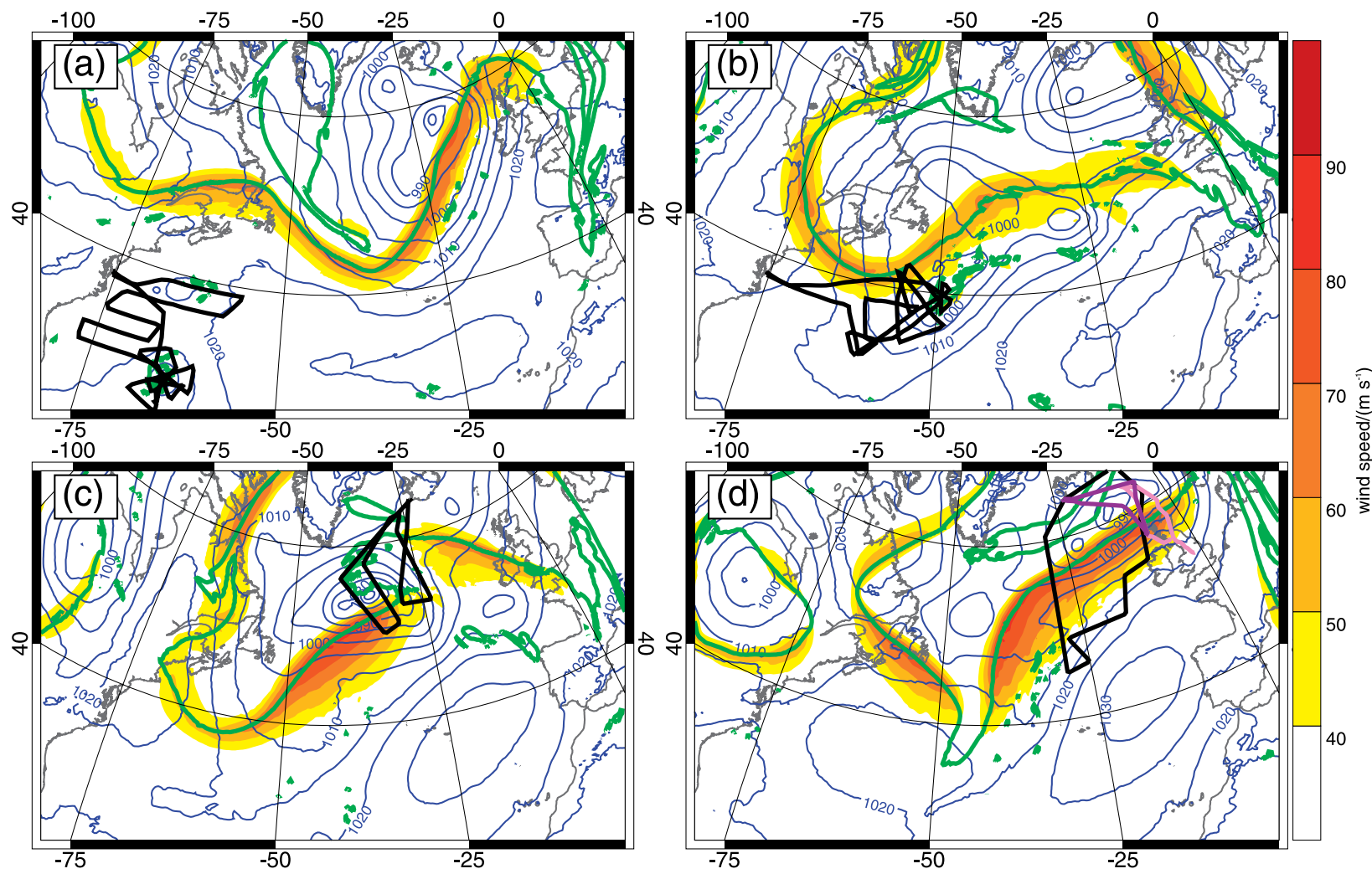

Fig. 7. ECMWF IFS operational analyses of wind speed (color shading), 2-PVU contour (green line) at $325 \mathrm{~K}$, and MSLP (blue contours; hPa) at (a) 1200 UTC 23 Sep 2016 with Global Hawk flight track (black line; from 2120 UTC 22 Sep to 2100 UTC 23 Sep), (b) 1200 UTC 25 Sep 2016 with Global Hawk flight track (black line; from 1820 UTC 24 Sep to 1715 UTC 25 Sep), (c) 1200 UTC 26 Sep 2016 with HALO flight track (black line; from 1000 to 1900 UTC), and (d) I200 UTC 27 Sep 2016 with HALO (black line; II30-2030 UTC), FAAM (pink line; 0800-1230 UTC), and DLR Falcon (purple line; 0930-1330 UTC) flight tracks. 
related to Cyclone Vladiana. On both crossings of the waveguide, one west to east and one east to west, a tilted dry layer is visible at altitudes between 5 and $9 \mathrm{~km}$ (1110-1125 and 1305-1325 UTC), related to a dry intrusion west of the low-level cold front. The wedge-shaped moist layer on top is associated with high moisture values in the WCB outflow. The second crossing at high altitudes depicts a strong vertical moisture gradient, on top of the elevated moist layer, that marks the tropopause and extends farther east into the area where WCB clouds reach high altitudes. A decrease of the tropopause height is detected toward the west on the second leg. The radar shows two vertically $(\sim 11.5 \mathrm{~km})$ and horizontally $(\sim 400 \mathrm{~km})$ extended and coherent clouds (Fig. 8c) representing the double crossing of the WCB. In between (i.e., on the eastern side of the WCB), cloud tops are lower and the clouds are intermittent. The sharp vertical gradient in radar reflectivity at about $3-\mathrm{km}$ altitude marks the melting layer.

On the second transect the FAAM aircraft performed in situ measurements on flight legs beneath HALO (Figs. 8b,c). HALO met FAAM at the beginning of its second WCB leg (purple diamond marker in Fig. 8c), where FAAM started its lowest leg at about $3-\mathrm{km}$ altitude, just above the melting layer, with subsequent legs at 4,6 , and $7.5 \mathrm{~km}$. The in situ observations show that both mixed-phase and
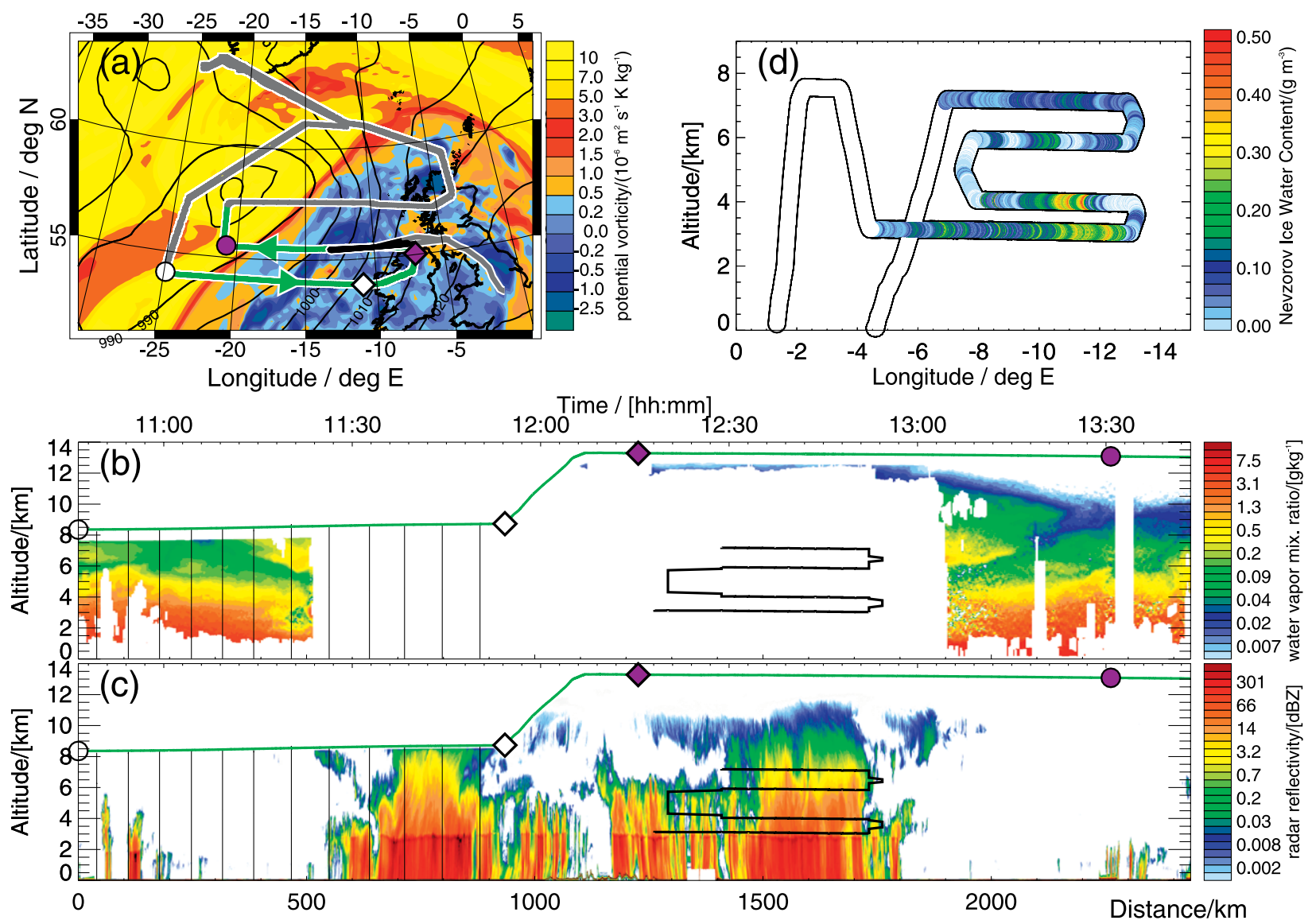

FIG. 8. WCB observations on 23 Sep 2016 (IOP 3): (a) ECMWF IFS operational analysis of PV at 325 K (shading) and MSLP (black contours; hPa) at 1200 UTC 23 Sep 2016 with the HALO flight track from Iceland [gray and green line, with the green part corresponding to the sections shown in (b) and (c)] and the FAAM flight track [gray and black line, with the black part corresponding to tracks in (b) and (c)]. The circle and diamond markers indicate the start and end positions of the latitudinal WCB cross sections. (b) WALES DIAL water vapor mixing ratio (colors) and (c) the HAMP radar reflectivity with HALO flight track (green line), FAAM flight track (thick black line; lowest leg was flown first), and dropsonde release positions (thin black lines). Only the part of the FAAM flight track with a spatial collocation to HALO is shown and both aircraft started at the same time but had a time lag of $\sim 2.5 \mathrm{~h}$ at the end of the last uppermost FAAM leg. (d) IWC as observed along the FAAM flight track. Differences between the flight tracks in (b), (c), and (d) result from interpolation of FAAM position to the closest HALO observation in (a). The longitude axis in (d) was reversed to align with the time axis of the HALO flight track. 
ice-only clouds were encountered during the lowlevel run, but during the high-level runs only ice was observed. The ice water content (IWC) in the WCB shows maximum values of $0.4 \mathrm{~g} \mathrm{~m}^{-3}$ on the lowest two legs (Fig. 8d). Ice images show large differences in the form of the particles at different altitudes. On the lowest leg, large aggregates $(\sim 6 \mathrm{~mm})$ dominate close to the freezing level, while at the highest level higher concentrations of small irregularly shaped crystals $(<1 \mathrm{~mm})$ prevail.

HALO also observed the interaction of Vladiana's WCB outflow with the jet stream in coordination with the DLR Falcon (not shown). IOP 3 contributes to all research aims (Table 3) and future work on the cloud microphysics observations will investigate, for example, the correlation of increased IWC with particularly high radar reflectivity. Data from liquid and ice particle size distributions will be used to improve the retrieval of cloud properties from the HALO remote sensing instruments. Overall, this is a unique set of comprehensive and complementary airborne observations of a WCB, its embedded microphysical processes, and its outflow interaction with the jet stream.

Wind observations in the jet stream and outflow of a WCB. Figure 6 (sequence B2) shows the stalactite cyclone that formed previously via merging of two near-surface vorticity maxima with a very intense, small-scale, upper-level PV anomaly south of Newfoundland (not shown). The rapid development of the cyclone occurred in the mid-Atlantic between 30 September and 2 October. On 2 October (IOP 6), a coordinated flight of the DLR and SAFIRE Falcons observed WCB ascent and outflow when the stalactite cyclone was most intense (Fig. 9a). The aircraft flew together to intersect the jet stream on the northwestern edge of ridge R5, wrapping cyclonically around the stalactite cyclone. On a common leg between Iceland and Greenland both aircraft crossed the jet stream (Fig. 9b) and made complementary wind observations (Figs. 9c,d). The Doppler wind lidar (DWL) on the DLR Falcon observed two wind maxima up to $50 \mathrm{~m} \mathrm{~s}^{-1}$ in cloud-free regions and in optically
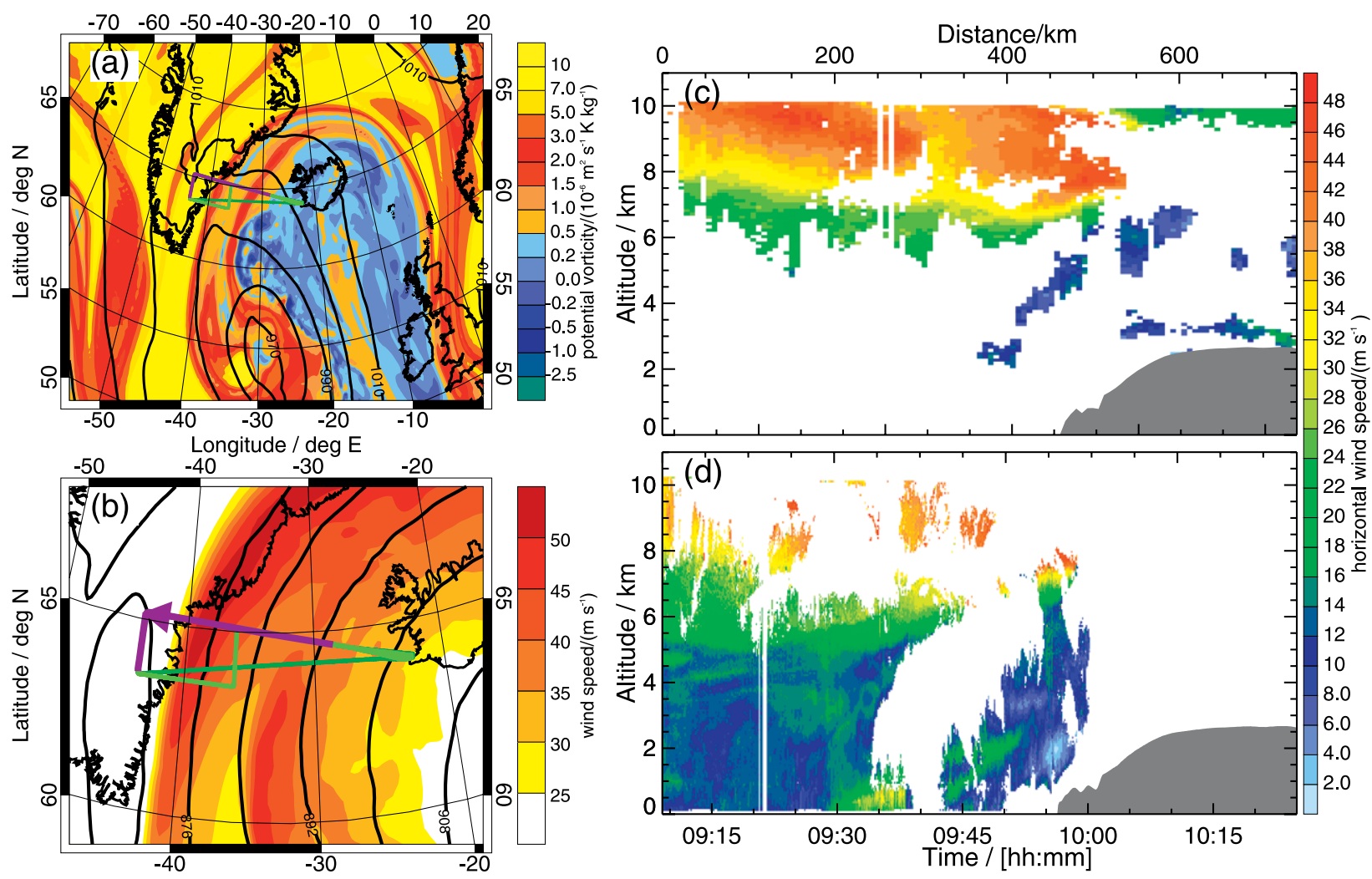

Fig. 9. Jet-stream observations on 2 Oct 2016 (IOP 6): (a) ECMWF IFS operational analysis of PV at $320 \mathrm{~K}$ (shading) and MSLP (black contours; $\mathrm{hPa}$ ), and (b) $300-\mathrm{hPa}$ wind speed (colors) and geopotential height (black contours; dam) at 0600 UTC 2 Oct 2016. Flight tracks in (a) and (b) are from the DLR Falcon (light green line) and SAFIRE Falcon (dark green line). The coordinated part of the flight from east to west shown in (c) and (d) is marked with the purple line. (c) DLR Falcon 2- $\mu \mathrm{m}$ DWL wind speeds (colors) and (d) SAFIRE radar-derived wind speeds (colors). Gray areas in (c) and (d) mark the topography of Greenland. 
thin cirrus in the WCB outflow. Complementarily, the SAFIRE radar observed in-cloud winds in the region of WCB ascent in the mid- and lower troposphere. Only in dry and aerosol-poor air masses over Greenland (i.e., on the stratospheric side of the waveguide) does the combination of both instruments provide poor data coverage. The SAFIRE Falcon released nine dropsondes when crossing the jet stream, yielding further profiles of winds, temperature, and moisture.

Future research on IOP 6 will be mainly dedicated to predictability issues associated with the blocking formation downstream of the cyclone. The block formed at a time when a loss of predictability in the ECMWF forecasts occurred (Fig. 5b). Winds measured by the two aircraft will help to characterize the role of the WCB outflow in the ridge building. The observed high winds and strong vertical gradients were repeatedly observed on flights across the jet stream with observed maxima up to $80 \mathrm{~m} \mathrm{~s}^{-1}$ and were often related to strong vertical wind speed gradients up to $30 \mathrm{~m} \mathrm{~s}^{-1} \mathrm{~km}^{-1}$. A unique aspect of this example is the benefit of coordinated flights with complementary instruments to address one of the key objectives of NAWDEX (Tables 1 and 3): observing the strong wind shear and PV gradients near a WCB outflow.

HIW related to cutoff Cyclone Sanchez. Cutoff Sanchez was initiated in the central North Atlantic and reached southern Europe between 12 and 14 October 2016 (Fig. 6, sequence C). On its leading edge moisture was advected northward (Fig. 10a) on 13 October when it triggered heavy precipitation and strong winds over France and Italy. The 24-h accumulated precipitation in the Herault region reached $\sim 250 \mathrm{~mm}$ (a)

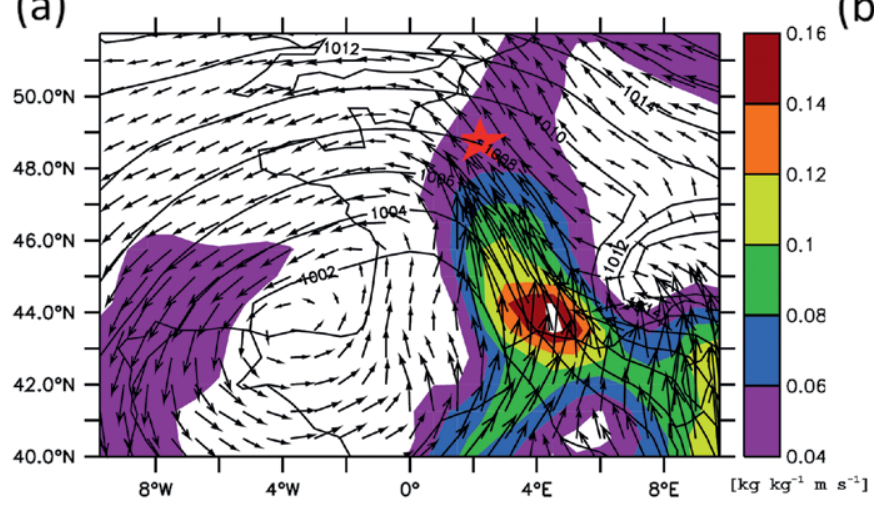

(c)

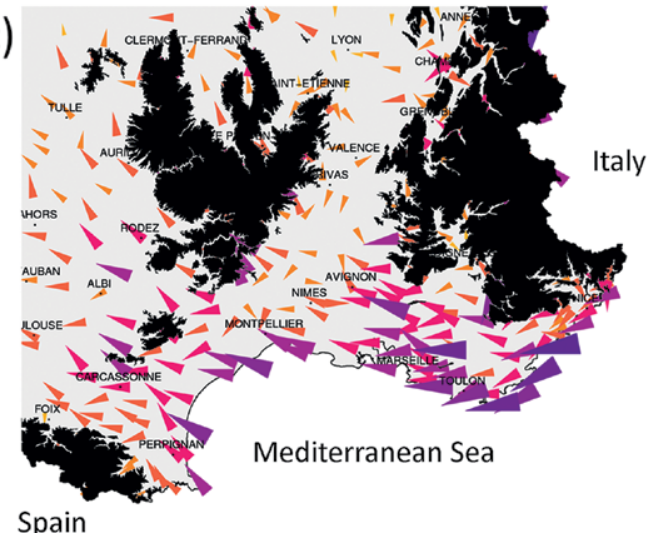

(b)
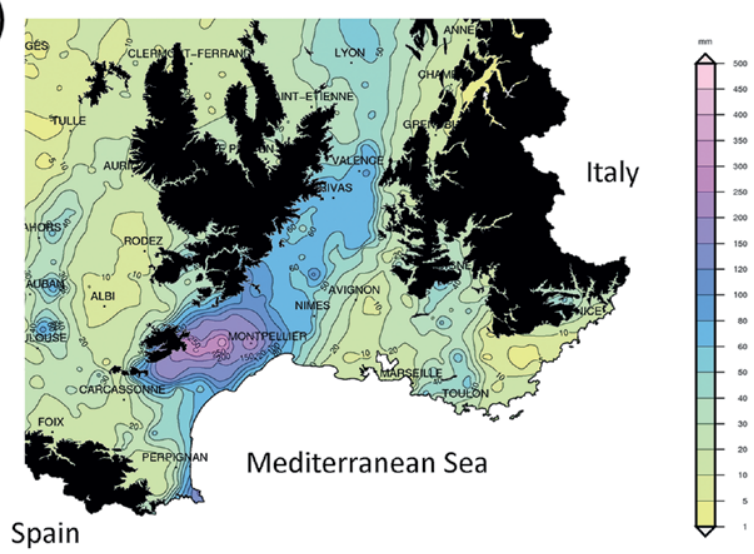

(d)
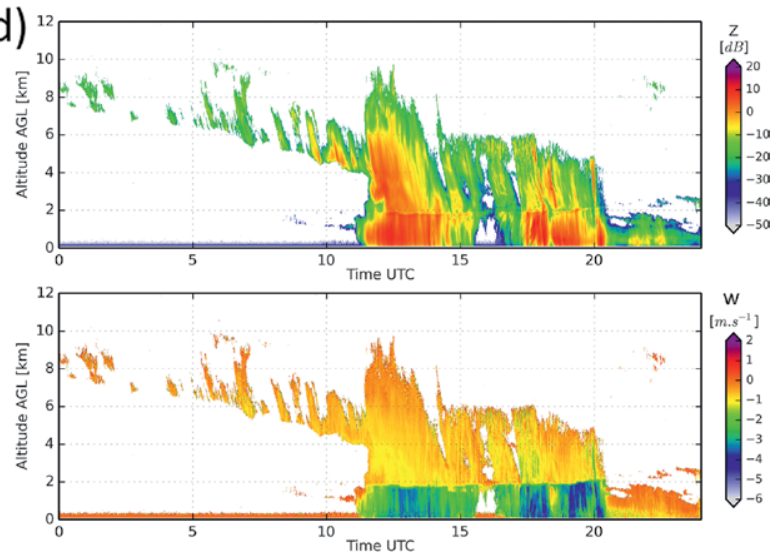

Fig. 10. (a) ERA-Interim moisture fluxes at $850 \mathrm{hPa}$ (arrows; shading shows magnitude) and surface pressure (black contours; $\mathrm{hPa}$ ) at 1200 UTC 13 Oct 2016. The red star indicates the location of the SIRTA surface observation site. (b) Daily accumulated precipitation $(\mathrm{mm})$ and (c) daily maximum of instantaneous surface wind in southern France on 13 Oct 2016 from the high-resolution climatological network of Météo-France surface weather stations. The black areas in (b) and (c) mark the topography of the French Pyrenees, the Massif Central, and the French Alps. (d) Reflectivity and Doppler velocity (approximately equal to terminal fall speed) at the $25-\mathrm{m}$ resolution of the BASTA radar at SIRTA on 13 Oct 2016. 
(Fig. 10b), and wind gusts exceeding $100 \mathrm{~km} \mathrm{~h}^{-1}$ were observed along the French Mediterranean coast (Fig. 10c). As in typical Cévenol episodes, strong southerlies brought warm and moist air from the Mediterranean Sea toward the Massif Central and caused heavy orographic precipitation over the mountain ranges of the Cevennes. Upper-level cutoffs like Sanchez are known to be favorable synoptic conditions for triggering convective mesoscale events (Nuissier et al. 2008), which were intensively studied during the recent Hydrological Cycle in the Mediterranean Experiment (HyMex) field campaign (Ducrocq et al. 2016). Part of the air masses responsible for the HIW subsequently reached as far north as the SIRTA site near Paris, causing precipitation during the afternoon of 13 October (Fig. 10d). This episode illustrates one of the key NAWDEX aims (Table 1), which is to investigate how HIW events over Europe are associated with complex waveguide dynamics (in this case the formation of a PV cutoff) over the upstream North Atlantic. The combination of the ground-based data with NAWDEX observations both from aircraft and from the many additional radiosondes taken during IOP 9 will enable detailed studies of the forecast sensitivity of HIW to upstream initial condition errors.

SUMMARY. NAWDEX was the first field experiment with synergistic airborne and ground-based observations from the entrance region to the exit region of the climatological storm track, and was undertaken to investigate the role of diabatic processes in altering jet-stream disturbances, their development, and their effects on HIW downstream.

Because of the operational limitations on research aircraft flights over the North Atlantic and Europe and the need for high-resolution profile measurements of thermal and dynamic properties, NAWDEX focused on airborne remote sensing observations and the deployment of multiple aircraft. Advanced instruments for remote sensing of wind, water vapor, and cloud properties provide an integrated picture of the atmospheric structure in regions where diabatic processes were active, from the synoptic to subkilometer scale. The unique combination of the four aircraft and the first deployment of HALO in a campaign focusing on midlatitude dynamics allowed observations over large parts of the North Atlantic. Often, the same weather system could be sampled at different stages of its development, and the interactions of successive weather systems have been observed following the NAWDEX storyline. Additional ground-based observations and an enhanced density of operational radiosonde releases yielded very high coverage with high-resolution vertical profiles from the ground to the lower stratosphere. The region with enhanced atmospheric profiling extended from eastern Canada to most parts of Europe. The coverage and fidelity of the resulting observations will enable future studies to estimate diabatic heating through the use of models and diagnostics constrained by the NAWDEX observations, particularly in situations when the atmospheric flow is especially sensitive to small changes in diabatic heating. Over the 13 IOPs it was possible to address all of the original campaign objectives (Tables 1 and 3). Table 5 lists a number of particular highlights and "firsts" that have drawn the attention of the NAWDEX scientists.

The success of the observational campaign was possible because of the favorable meteorological conditions, with many cyclones and WCBs in the vicinity of Iceland. Importantly, the NAWDEX period contained episodes of reduced predictability, indicating that uncertainties originating in the estimated atmospheric state and model formulation grew rapidly. The suggestion that these uncertainties spread via their impact on the life cycle of a "second cyclone" forming to the west, rather than through a process of downstream development, shows that NAWDEX has the potential to make an important contribution to the study of predictability of midlatitude weather and the representation of uncertainty in EPSs. Since there were also episodes of HIW in Europe connected to disturbances of the North Atlantic waveguide, NAWDEX also offered a unique opportunity to explore HIW predictability.

To the best of our knowledge, the NAWDEX period provides the most complete set of combined wind, humidity, temperature, and cloud profile observations of the North Atlantic jet stream yet assembled. This dataset will form the basis of detailed case studies and evaluations of weather and climate prediction models for many years. The widespread coverage of high-resolution multivariate cross sections across the jet stream and weather systems developing from one side of the North Atlantic to the other enables examination of the whole chain of processes from the triggering of disturbances on the waveguide to the ultimate impact on weather systems affecting Europe.

ACKNOWLEDGMENTS. Many international institutions contributed to the implementation of NAWDEX and the results presented in this overview article. 
NAWDEX was only possibly due to the close cooperation of many colleagues including the planning team, the instrument groups, and the flight operation crews (appendix). The HALO and DLR Falcon campaign received funding from DLR [project "Klimarelevanz von atmosphärischen Spurengasen, Aerosolen und Wolken" (KliSAW)], ETH Zürich, NRL Monterey, the German Science Foundation (DFG; within SPP1294 HALO and SFB/ TRR165 Waves to Weather), the European Facility for Airborne Research (EUFAR; project NAWDEX-Influence), and the European Space Agency (ESA), providing funds related to the preparation of Aeolus (WindVal II, Contract 4000114053/15/NL/FF/gp) and EarthCARE (EPATAN, Contract 4000119015/16/NL/CT/gp). Special thanks are due to the Max Planck Institute Hamburg for sharing the HALO payload during the NARVAL-II and NAWDEX campaigns in summer and fall 2016 and for their general support of NAWDEX. We are grateful to the DLR flight experiments team, in particular, the colleagues of flight operations for the careful preparation and the outstanding support in Keflavik. The authors are grateful to the HALO and Falcon pilots and the technical and sensor team from DLR flight operations for excellent support prior to and during NAWDEX. The SAFIRE Falcon contribution to NAWDEX received direct funding from L'Institut PierreSimon Laplace (IPSL), Météo-France, Institut National des Sciences de l'Univers (INSU) via the LEFE program, EUFAR Norwegian Mesoscale Ensemble and Atmospheric River Experiment (NEAREX), and ESA (EPATAN, Con- tract 4000119015/16/NL/CT/gp). The U.K. funding for the FAAM aircraft flights, dropsondes, and additional radiosondes was provided by the Met Office. Special thanks are due to the SHOUT mission for their open collaboration, which enabled coordinated observations of Tropical Storm Karl. Observations at Capel Dewi were funded by the National Centre for Atmospheric Science (NCAS). We thank the European Meteorological Service Network (EUMETNET) for funding additional radiosondes and for providing access to the data. Environment and Climate Change Canada (ECCC) provided funding for enhanced radiosonde frequency during the campaign. The Icelandic Meteorological Office (IMO) and DLR are thanked for providing additional radiosondes from Iceland. We thank ECMWF for providing access to data within the framework of the Support Tool for HALO Missions (SPDEHALO) special project. We gratefully acknowledge many discussions with U.S. colleagues, in particular Chris Davis, Pat Harr, and Heather Archambault, during the scientific preparation of NAWDEX. We thank Michael Sprenger (ETH Zürich) for preparing the data used in Fig. 4. MB and CMG acknowledge funding from the Swiss National Science Foundation (Projects 200020_165941 and PZ00P2_148177, respectively). JDD and CAR acknowledge the support of the U.S. Navy Chief of Naval Research through the NRL Base Program PE 0601153N, and the ONR PE 0602435N. We are very grateful to three anonymous reviewers for their constructive comments that helped to improve the manuscript.

APPENDIX: THE NAWDEX TEAMS. Table A1 shows the NAWDEX participants, along with their affiliation and role(s) in the campaign.

\begin{tabular}{|c|c|c|c|}
\hline Organization & Country & Participant(s) & Role \\
\hline Monash University & Australia & Julian Quinting & Flight-planning team \\
\hline ECCC & Canada & Ron McTaggart-Cowan & $\begin{array}{l}\text { Principal investigator }(\mathrm{PI}) \text { for } \\
\text { Canadian radiosondes, science team }\end{array}$ \\
\hline INSU & France & Frédéric Blouzon & RALI team \\
\hline IPSL & France & Jean-Charles Dupont & $\begin{array}{l}\text { Coordinator of radiosonde } \\
\text { launches at SIRTA }\end{array}$ \\
\hline Laboratoire d'Aérologie & France & Jean-Pierre Chaboureau & Flight-planning team \\
\hline $\begin{array}{l}\text { Laboratoire de Météorologie } \\
\text { Dynamique }\end{array}$ & France & Gwendal Rivière & Science team, flight-planning team \\
\hline \multirow[t]{2}{*}{$\begin{array}{l}\text { Laboratoire Atmosphère, Milieux } \\
\text { et Observations Spatiales France }\end{array}$} & \multirow[t]{2}{*}{ France } & Julien Delanoë & Science team, flight-planning team \\
\hline & & $\begin{array}{l}\text { Christophe Caudoux, Quitterie } \\
\text { Cazenave,Abdenour Irbah, } \\
\text { Mathilde Van Haecke }\end{array}$ & RALI team (airborne radar-lidar) \\
\hline \multirow[t]{2}{*}{ Météo-France } & \multirow[t]{2}{*}{ France } & Philippe Arbogast & Science team, flight-planning team \\
\hline & & Jean-Marie Donier & UHF radar at Lannion \\
\hline
\end{tabular}


Table Al. Continued.

\begin{tabular}{|c|c|c|c|}
\hline Organization & Country & Participant(s) & Role \\
\hline \multirow[t]{3}{*}{ SAFIRE } & France & Jean-Christophe Canonici & SAFIRE coordinator \\
\hline & & $\begin{array}{l}\text { Dominique Duchanoy, Guillaume } \\
\text { Seurat }\end{array}$ & Falcon pilots \\
\hline & & $\begin{array}{l}\text { Hubert Bellec, Nelly Geil, David } \\
\text { Mourlas, Thierry Perrin, Frédéric } \\
\text { Pouvesle }\end{array}$ & Falcon technical support \\
\hline \multirow[t]{5}{*}{ DLR, flight experiments } & Germany & $\begin{array}{l}\text { Andreas Minikin, Robert } \\
\text { Uebelacker, Katrin Witte }\end{array}$ & $\begin{array}{l}\text { HALO and Falcon project } \\
\text { management }\end{array}$ \\
\hline & & Stefan Hempe, Frank Probst & HALO and Falcon operations \\
\hline & & $\begin{array}{l}\text { Steffen Gemsa, Michael } \\
\text { Grossrubatscher, Stefan Grillenbeck, } \\
\text { Philipp Weber, Roland Welser, } \\
\text { Matthias Wiese }\end{array}$ & HALO and Falcon pilots \\
\hline & & $\begin{array}{l}\text { Volker Dreiling,Andreas Giez, } \\
\text { Christian Mallaun, Martin Zöger }\end{array}$ & $\begin{array}{l}\text { HALO and Falcon sensor and } \\
\text { data team }\end{array}$ \\
\hline & & $\begin{array}{l}\text { Michael Kettenberger, Thomas } \\
\text { Leder, Florian Gebhardt, } \\
\text { Christoph Grad, Stephan Storhas, } \\
\text { David Woudsma }\end{array}$ & HALO technical support \\
\hline \multirow[t]{5}{*}{$\begin{array}{l}\text { DLR, Institute for Atmospheric } \\
\text { Physics }\end{array}$} & Germany & Andreas Schäfler & $\begin{array}{l}\text { Mission coordinator, science team, } \\
\text { flight-planning team }\end{array}$ \\
\hline & & $\begin{array}{l}\text { Axel Amediek, Andreas Fix, Silke } \\
\text { Groß, Manuel Gutleben, Martin Wirth }\end{array}$ & WALES team \\
\hline & & $\begin{array}{l}\text { Christian Lemmerz, Oliver Lux, } \\
\text { Uwe Marksteiner, Engelbert Nagel, } \\
\text { Stephan Rahm, Oliver Reitebuch, } \\
\text { Benjamin Witschas }\end{array}$ & Wind lidar team \\
\hline & & Florian Ewald, Martin Hagen & HAMP team \\
\hline & & $\begin{array}{l}\text { Martina Bramberger, } \\
\text { Alenka Senika }\end{array}$ & $\begin{array}{l}\text { Radiosonde team at Keflavik, } \\
\text { flight-planning team }\end{array}$ \\
\hline Karlsruhe Institute of Technology & Germany & $\begin{array}{l}\text { Pila Bossmann, Enrico Di Muzio, } \\
\text { Florian Pantillion }\end{array}$ & Flight-planning team \\
\hline $\begin{array}{l}\text { Max Planck Institute for } \\
\text { Meteorology (MPI-M) }\end{array}$ & Germany & $\begin{array}{l}\text { Björn Brügmann, David Hellmann, } \\
\text { Lutz Hirsch, Friedhelm Jansen, } \\
\text { Marcus Klingebiel }\end{array}$ & HAMP team \\
\hline Technical University of Munich & Germany & Marc Rautenhaus & Flight-planning team \\
\hline University of Cologne & Germany & $\begin{array}{l}\text { Susanne Crewell, Lisa Dirks, } \\
\text { Marek Jacob, Mario Mech }\end{array}$ & HAMP team \\
\hline University of Hamburg and MPI-M & Germany & Felix Ament, Heike Konow & HAMP team \\
\hline University of Leipzig & Germany & $\begin{array}{l}\text { Tim Carlsen, André Ehrlich, } \\
\text { Manfred Wendisch, Kevin Wolf, }\end{array}$ & SMART team \\
\hline University of Mainz & Germany & $\begin{array}{l}\text { Marlene Baumgart, Christian Euler, } \\
\text { Paolo Ghinassi, Michael Riemer, } \\
\text { Volkmar Wirth }\end{array}$ & Flight-planning team \\
\hline \multirow[t]{3}{*}{ University of Munich } & Germany & George Craig & $\begin{array}{l}\text { HALO mission PI, } \\
\text { science team, flight-planning team }\end{array}$ \\
\hline & & $\begin{array}{l}\text { Florian Baur, Lotte Bierdel, Christian } \\
\text { Keil, Julia Mack, Tobias Selz }\end{array}$ & Flight-planning team \\
\hline & & $\begin{array}{l}\text { Hans Grob, Lucas Höppler, } \\
\text { Tobias Kölling, Bernhard Mayer, } \\
\text { Tobias Zinner }\end{array}$ & SpecMACS team \\
\hline
\end{tabular}


TABle Al. Continued.

\begin{tabular}{|c|c|c|c|}
\hline Organization & Country & Participant(s) & Role \\
\hline Norwegian Meteorological Institute & Norway & Rich Moore & NEAREX team \\
\hline University of Bergen & Norway & $\begin{array}{l}\text { Harald Sodemann, Thomas } \\
\text { Spengler }\end{array}$ & NEAREX team \\
\hline $\begin{array}{l}\text { National Institute of Research and } \\
\text { Development for Optoelectronics }\end{array}$ & Romania & Dragos Ene & Flight-planning team \\
\hline \multirow[t]{2}{*}{ ETH Zürich } & \multirow[t]{2}{*}{ Switzerland } & Heini Wernli & Science team, flight-planning team \\
\hline & & $\begin{array}{l}\text { Roman Attinger, Hanin Binder, } \\
\text { Maxi Boettcher, Bas Crezee, } \\
\text { Christian Grams, Jacopo Riboldi }\end{array}$ & Flight-planning team \\
\hline University of Bern & Switzerland & Matthias Röthlisberger & Flight-planning team \\
\hline Met Office & $\begin{array}{l}\text { United } \\
\text { Kingdom }\end{array}$ & Richard Cotton, Stuart Fox & FAAM aircraft \\
\hline $\begin{array}{l}\text { NCAS and University of } \\
\text { Manchester }\end{array}$ & $\begin{array}{l}\text { United } \\
\text { Kingdom }\end{array}$ & $\begin{array}{l}\text { Bogdan Antonescu, } \\
\text { Hugo Ricketts, Geraint Vaughan }\end{array}$ & $\begin{array}{l}\text { Capel Dewi observations, FAAM } \\
\text { aircraft }\end{array}$ \\
\hline \multirow[t]{2}{*}{ University of Reading and NCAS } & \multirow[t]{2}{*}{$\begin{array}{l}\text { United } \\
\text { Kingdom }\end{array}$} & Suzanne Gray, John Methven & $\begin{array}{l}\text { FAAM aircraft, NAWDEX-Influence } \\
\text { PIs, science team, flight-planning } \\
\text { team }\end{array}$ \\
\hline & & $\begin{array}{l}\text { Ben Harvey, Jacob Maddison, } \\
\text { Oscar Martínez-Alvarado, } \\
\text { Leo Saffin }\end{array}$ & Flight-planning team \\
\hline \multirow{2}{*}{$\begin{array}{l}\text { NRL Monterey, CA, and } \\
\text { Washington, DC }\end{array}$} & \multirow{2}{*}{$\begin{array}{l}\text { United } \\
\text { States }\end{array}$} & James Doyle & Science team, flight-planning team \\
\hline & & $\begin{array}{l}\text { Stephen Eckermann, Carolyn } \\
\text { Reynolds }\end{array}$ & Flight-planning team \\
\hline EUMETNET & & Susanne Hafner, Stefan Klink & EUMETNET coordinators \\
\hline ESA & & Dirk Schüttemeyer & ESA campaign section \\
\hline
\end{tabular}

\section{REFERENCES}

Agusti-Panareda, A., C. D. Thorncroft, G. C. Craig, and S. L. Gray, 2004: The extratropical transition of Hurricane Irene (1999): A potential-vorticity perspective. Quart. J. Roy. Meteor. Soc., 130, 1047-1074, https://doi.org/10.1256/qj.02.140.

Archambault, H. M., L. F. Bosart, D. Keyser, and J. M. Cordeira, 2013: A climatological analysis of the extratropical flow response to recurving western North Pacific tropical cyclones. Mon. Wea. Rev., 141, 23252346, https://doi.org/10.1175/MWR-D-12-00257.1.

Bauer, P., A. Thorpe, and G. Brunet, 2015: The quiet revolution of numerical weather prediction. Nature, 525, 47-55, https://doi.org/10.1038/nature14956.

Binder, H., M. Boettcher, H. Joos, and H. Wernli, 2016: The role of warm conveyor belts for the intensification of extratropical cyclones in Northern Hemisphere winter. J. Atmos. Sci., 73, 3997-4020, https:// doi.org/10.1175/JAS-D-15-0302.1.

Brogniez, G., C. Pietras, M. Legrand, P. Dubuisson, and M. Haeffelin, 2003: A high-accuracy multiwavelength radiometer for in situ measurements in the thermal infrared. Part II: Behavior in field experiments. J. Atmos. Oceanic Technol., 20, 1023-1033, https://doi.org/10.1175/1520-0426(2003)20<1023:AH MRFI>2.0.CO;2.

Browning, K. A., M. E. Hardman, T. W. Harrold, and C. W. Pardoe, 1973: Structure of rainbands within a mid-latitude depression. Quart. J. Roy. Meteor. Soc., 99, 215-231, https://doi.org/10.1002/qj .49709942002 .

Bruneau, D., and Coauthors, 2015: 355-nm high spectral resolution airborne lidar LNG: System description and first results. Appl. Opt., 54, 8776-8785, https:// doi.org/10.1364/AO.54.008776.

Carlson, T. N., 1980: Airflow through midlatitude cyclones and the comma cloud pattern. Mon. Wea. Rev., 108, 1498-1509, https://doi.org/10.1175/1520 -0493(1980)108<1498:ATMCAT>2.0.CO;2.

Cavallo, S. M., and G. J. Hakim, 2010: Composite structure of tropopause polar cyclones. Mon. Wea. Rev., 138, 3840-3857, https://doi.org/10.1175/2010MWR3371.1.

Cavallo, S. M., and G. J. Hakim, 2012: Radiative impact on tropopause polar vortices over the Arctic. Mon. Wea. Rev., 140, 1683-1702 
Chaboureau, J.-P., and C. Claud, 2006: Satellite-based climatology of Mediterranean cloud systems and their association with large-scale circulation. J. Geophys. Res., 111, D01102, https://doi .org/10.1029/2005JD006460.

Chagnon, J., S. L. Gray, and J. Methven, 2013: Diabatic processes modifying potential vorticity in a North Atlantic cyclone. Quart. J. Roy. Meteor. Soc., 139, 1270-1282, https://doi.org/10.1002/qj.2037.

Davis, C. A., M. T. Stoelinga, and Y.-H. Kuo, 1993: The integrated effect of condensation in numerical simulations of extratropical cyclogenesis. Mon. Wea. Rev., 121, 2309-2330, https://doi.org/10.1175/1520 -0493(1993)121<2309:TIEOCI>2.0.CO;2.

Dearden, C., P. J. Connolly, G. Lloyd, J. Crosier, K. N. Bower, T. W. Choularton, and G. Vaughan, 2014: Diabatic heating and cooling rates derived from in situ microphysics measurements: A case study of a wintertime U.K. cold front. Mon. Wea. Rev., 142, 3100-3125, https://doi.org/10.1175/MWR -D-14-00048.1.

Delanoë, J., A. Protat, O. Jourdan, J. Pelon, M. Papazzoni, R. Dupuy, J.-F. Gayet, and C. Jouan, 2013: Comparison of airborne in situ, airborne radar-lidar, and spaceborne radar-lidar retrievals of polar ice cloud properties sampled during the POLARCAT campaign. J. Atmos. Oceanic Technol., 30, 57-73, https:// doi.org/10.1175/JTECH-D-11-00200.1.

— , and Coauthors, 2016: BASTA: A 95-GHz FMCW Doppler radar for cloud and fog studies. J. Atmos. Oceanic Technol., 33, 1023-1038, https://doi.org /10.1175/JTECH-D-15-0104.1.

Doyle, J. D., C. Amerault, C. A. Reynolds, and P. A. Reinecke, 2014: Initial condition sensitivity and predictability of a severe extratropical cyclone using a moist adjoint. Mon. Wea. Rev., 142, 320-342, https:// doi.org/10.1175/MWR-D-13-00201.1.

Ducrocq, V., S. Davolio, R. Ferretti, C. Flamant, V. H. Santaner, N. Kalthoff, E. Richard, and H. Wernli, 2016: Introduction to the HyMeX Special Issue on 'Advances in understanding and forecasting of heavy precipitation in the Mediterranean through the HyMeX SOP1 field campaign.' Quart. J. Roy. Meteor. Soc., 142, 1-6, https://doi.org/10.1002/qj.2856.

Ehrlich, A., E. Bierwirth, M. Wendisch, J.-F. Gayet, G. Mioche, A. Lampert, and J. Heintzenberg, 2008: Cloud phase identification of Arctic boundary-layer clouds from airborne spectral reflection measurements: Test of three approaches. Atmos. Chem. Phys., 8, 7493-7505, https://doi.org/10.5194/acp-8 -7493-2008.

ESA, 2008: ADM-Aeolus science report. European Space Agency Science Rep. SP-1311, 121 pp., http://
esamultimedia.esa.int/docs/SP-1311_ADM-Aeolus _FINAL_low-res.pdf.

Ewald, F., T. Kölling, A. Baumgartner, T. Zinner, and B. Mayer, 2016: Design and characterization of specMACS, a multipurpose hyperspectral cloud and sky imager. Atmos. Meas. Tech., 9, 2015-2042, https:// doi.org/10.5194/amt-9-2015-2016.

Frame, T. H. A., J. Methven, N. M. Roberts, and H. A. Titley, 2015: Predictability of frontal waves and cyclones. Wea. Forecasting, 30, 1291-1302, https://doi .org/10.1175/WAF-D-15-0039.1.

Grams, C. M., and S. R. Blumer, 2015: European highimpact weather caused by the downstream response to the extratropical transition of North Atlantic Hurricane Katia (2011). Geophys. Res. Lett., 42, 8738-8748, https://doi.org/10.1002/2015GL066253.

- and H. M. Archambault, 2016: The key role of diabatic outflow in amplifying the midlatitude flow: A representative case study of weather systems surrounding western North Pacific extratropical transition. Mon. Wea. Rev., 144, 3847-3869, https:// doi.org/10.1175/MWR-D-15-0419.1.

— cesses in modifying the upper tropospheric wave guide: A North Atlantic case-study. Quart. J. Roy. Meteor. Soc., 137, 2174-2193, https://doi.org/10.1002/qj.891.

Gray, S. L., C. Dunning, J. Methven, G. Masato, and J. Chagnon, 2014: Systematic model forecast error in Rossby wave structure. Geophys. Res. Lett., 41, 2979-2987, https://doi.org/10.1002/2014GL059282.

Hadlock, R., and C. W. Kreitzberg, 1988: The Experiment on Rapidly Intensifying Cyclones over the Atlantic (ERICA) field study: Objectives and plans. Bull. Amer. Meteor. Soc., 69, 1309-1320, https://doi .org/10.1175/1520-0477(1988)069<1309:TEORIC $>2.0 . \mathrm{CO} ; 2$.

Haeffelin, M., and Coauthors, 2005: SIRTA, a groundbased atmospheric observatory for cloud and aerosol research. Ann. Geophys., 23, 253-275, https://doi .org/10.5194/angeo-23-253-2005.

Harr, P. A., D. Anwender, and S. C. Jones, 2000: Predictability associated with the downstream impacts of the extratropical transition of tropical cyclones: Methodology and a case study of Typhoon Nabi (2005). Mon. Wea. Rev., 128, 2613-2633, https://doi .org/10.1175/1520-0493(2000)128<2613:ETOTCO $>2.0 . \mathrm{CO} ; 2$.

Harvey, B., J. Methven, and M. Ambaum, 2016: Rossby wave propagation on potential vorticity fronts with finite width. J. Fluid Mech., 794, 775-797, https://doi .org/10.1017/jfm.2016.180.

Illingworth, A. J., and Coauthors, 2015: The EarthCARE satellite: The next step forward in global 
measurements of clouds, aerosols, precipitation, and radiation. Bull. Amer. Meteor. Soc., 96, 1311-1332, https://doi.org/10.1175/BAMS-D-12-00227.1.

Joly, A., and Coauthors, 1999: Overview of the field phase of the Fronts and Atlantic Storm-Track Experiment (FASTEX) project. Quart. J. Roy. Meteor. Soc., 125, 3131-3163, https://doi.org/10.1002/qj.49712556103.

Jones, S. C., and B. Golding, 2015: High Impact Weather Project (HIWeather). World Weather Research Programme, www.wmo.int/pages/prog/arep/wwrp/new /high_impact_weather_project.html.

— of tropical cyclones: Forecast challenges, current understanding, and future directions. Wea. Forecasting, 18, 1052-1092, https://doi.org/10.1175/1520-0434 (2003)018<1052:TETOTC>2.0.CO;2.

Joos, H., and H. Wernli, 2012: Influence of microphysical processes on the potential vorticity development in a warm conveyor belt: A case-study with the limited-area model COSMO. Quart. J. Roy. Meteor. Soc., 138, 407-418, https://doi.org/10.1002/qj.934.

— , and R. Forbes, 2016: Impact of different IFS microphysics on a warm conveyor belt and the downstream flow evolution. Quart. J. Roy. Meteor. Soc., 142, 2727-2739, https://doi.org/10.1002/qj.2863.

Kew, S. F., M. Sprenger, and H. C. Davies, 2010: Potential vorticity anomalies of the lowermost stratosphere: A 10-yr winter climatology. Mon. Wea. Rev., 138, 1234-1249, https://doi.org/10.1175/2009MWR3193.1.

Knippertz, P., and J. E. Martin, 2005: Tropical plumes and extreme precipitation in subtropical and tropical West Africa. Quart. J. Roy. Meteor. Soc., 131, 2337-2365, https://doi.org/10.1256/qj.04.148.

Krautstrunk, M., and A. Giez, 2012: The transition from FALCON to HALO era airborne atmospheric research. Atmospheric Physics: Background - Methods - Trends, U. Schumann, Ed., Research Topics in Aerospace, Vol. 1, Springer-Verlag, 604-629.

Kuo, Y. H., M. A. Shapiro, and E. G. Donall, 1991: The interaction between baroclinic and diabatic processes in a numerical simulation of a rapidly intensifying extratropical marine cyclone. Mon. Wea. Rev., 119, 368-384, https://doi.org/10.1175/1520 -0493(1991)119<0368:TIBBAD>2.0.CO;2.

Lavers, D. A., and G. Villarini, 2013: The nexus between atmospheric rivers and extreme precipitation across Europe. Geophys. Res. Lett., 40, 3259-3264, https:// doi.org/10.1002/grl.50636.

Madonna, E., H. Wernli, H. Joos, and O. Martius, 2014: Warm conveyor belts in the ERA-Interim dataset (1979-2010). Part I: Climatology and potential vorticity evolution. J. Climate, 27, 3-26, https://doi .org/10.1175/JCLI-D-12-00720.1.
—, M. Boettcher, C. M. Grams, H. Joos, O. Martius, and H. Wernli, 2015: Verification of North Atlantic warm conveyor belt outflows in ECMWF forecasts. Quart. J. Roy. Meteor. Soc., 141, 1333-1344, https:// doi.org/10.1002/qj.2442.

Majumdar, S. J., 2016: A review of targeted observations. Bull. Amer. Meteor. Soc., 97, 2287-2303, https://doi .org/10.1175/BAMS-D-14-00259.1.

Marksteiner, U., O. Reitebuch, S. Rahm, I. Nikolaus, C. Lemmerz, and B. Witschas, 2011: Airborne directdetection and coherent wind lidar measurements along the east coast of Greenland in 2009 supporting ESA's Aeolus mission. Lidar Technologies, Techniques, and Measurements for Atmospheric Remote Sensing VII, U. N. Singh and G. Pappalardo, Eds., Society of Photo-Optical Instrumentation Engineers (SPIE Proceedings, Vol. 8182), 81820J, https://doi.org/10.1117/12.897528.

Martínez-Alvarado, O., H. Joos, J. Chagnon, M. Boettcher, S. L. Gray, R. S. Plant, J. Methven, and H. Wernli, 2014: The dichotomous structure of the warm conveyor belt. Quart. J. Roy. Meteor. Soc., 140, 1809-1824, https://doi.org/10.1002/qj.2276.

__, E. Madonna, S. L. Gray, and H. Joos, 2016: A route to systematic error in forecasts of Rossby waves. Quart. J. Roy. Meteor. Soc., 142, 196-210, https://doi .org/10.1002/qj.2645.

Martius, O., E. Zenklusen, C. Schwierz, and H. C. Davies, 2006: Episodes of Alpine heavy precipitation with an overlying elongated stratospheric intrusion: A climatology. Int. J. Climatol., 26, 1149-1164, https:// doi.org/10.1002/joc.1295.

— C. Schwierz, and H. C. Davies, 2010: Tropopauselevel waveguides. J. Atmos. Sci., 67, 866-879, https:// doi.org/10.1175/2009JAS2995.1.

Massacand, A. C., H. Wernli, and H. C. Davies, 2001: Influence of upstream diabatic heating upon an alpine event of heavy precipitation. Mon. Wea. Rev., 129, 2822-2828, https://doi.org/10.1175/1520 -0493(2001)129<2822:IOUDHU>2.0.CO;2.

Mech, M., E. Orlandi, S. Crewell, F. Ament, L. Hirsch, M. Hagen, G. Peters, and B. Stevens, 2014: HAMPThe Microwave Package on the High Altitude and Long Range Research Aircraft (HALO). Atmos. Meas. Tech., 7, 4539-4553, https://doi.org/10.5194 lamt-7-4539-2014.

Methven, J., 2015: Potential vorticity in warm conveyor belt outflow. Quart. J. Roy. Meteor. Soc., 141, 1065-1071, https://doi.org/10.1002/qj.2393.

Michel, C., and G. Rivière, 2011: A link between Rossby wave breakings and weather regime transitions. J. Atmos. Sci., 68, 1730-1748, https://doi .org/10.1175/2011JAS3635.1. 
Michelangeli, P., R. Vautard, and B. Legras, 1995: Weather regimes: Recurrence and quasi stationarity. J. Atmos. Sci., 52, 1237-1256, https://doi .org/10.1175/1520-0469(1995)052<1237:WRRAQS $>2.0 . \mathrm{CO} ; 2$.

Neiman, P. J., M. A. Shapiro, and L. S. Fedor, 1993: The life cycle of an extratropical marine cyclone. Part II: Mesoscale structure and diagnostics. Mon. Wea. Rev., 121, 2177-2199, https://doi.org/10.1175/1520 -0493(1993)121<2177:TLCOAE>2.0.CO;2.

Nuissier, O., V. Ducrocq, D. Ricard, C. Lebeaupin, and S. Anquetin, 2008: A numerical study of three catastrophic precipitating events over southern France. I: Numerical framework and synoptic ingredients. Quart. J. Roy. Meteor. Soc., 134, 111-130, https://doi .org/10.1002/qj.200.

Parsons, D. B., and Coauthors, 2017: THORPEX research and the science of prediction. Bull. Amer. Meteor. Soc., 98, 807-830, https://doi.org/10.1175 /BAMS-D-14-00025.1.

Pfahl, S., C. Schwierz, M. Croc-Maspoli, C. M. Grams, and $\mathrm{H}$. Wernli, 2015: Importance of latent heat release in ascending air streams for atmospheric blocking. Nat. Geosci., 8, 610-614, https://doi.org/10.1038 /ngeo2487.

Pomroy, H. R., and A. J. Thorpe, 2000: The evolution and dynamical role of reduced upper-tropospheric potential vorticity in intensive observing period one of FASTEX. Mon. Wea. Rev., 128, 1817-1834, https://doi.org/10.1175/1520-0493(2000)128<1817: TEADRO $>2.0 . \mathrm{CO} ; 2$.

Protat, A., and Coauthors, 2004: Le projet RALI: Combinaison d'un radar nuage et d'un lidar pour l'étude des nuages faiblement précipitants. Meteorologie, No. 47, Meteo et Climat, Saint-Mandé, France, 23-33, https://doi.org/10.4267/2042/36076.

Rabier, F., and Coauthors, 2008: An update on THORPEX-related research in data assimilation and observing strategies. Nonlinear Processes Geophys., 15, 81-94, https://doi.org/10.5194/npg-15-81-2008.

Rautenhaus, M., G. Bauer, and A. Dörnbrack, 2012: A web service based tool to plan atmospheric research flights. Geosci. Model Dev., 5, 55-71, https://doi .org/10.5194/gmd-5-55-2012.

— - M. Kern, A. Schäfler, and R. Westermann, 2015a: Three-dimensional visualization of ensemble weather forecasts-Part 1: The visualization tool Met.3D (version 1.0). Geosci. Model Dev., 8, 23292353, https://doi.org/10.5194/gmd-8-2329-2015.

_ , C. M. Grams, A. Schäfler, and R. Westermann, 2015b: Three-dimensional visualization of ensemble weather forecasts-Part 2: Forecasting warm conveyor belt situations for aircraft-based field campaigns.
Geosci. Model Dev., 8, 2355-2377, https://doi .org/10.5194/gmd-8-2355-2015.

Reitebuch, O., C. Lemmerz, E. Nagel, U. Paffrath, Y. Durand, M. Endemann, F. Fabre, and M. Chaloupy, 2009: The airborne demonstrator for the direct-detection Doppler wind lidar ALADIN on ADM-Aeolus. Part I: Instrument design and comparison to satellite instrument. $J$. Atmos. Oceanic Technol., 26, 2501-2515, https://doi .org/10.1175/2009JTECHA1309.1.

Rex, D. F., 1950: Blocking action in the middle troposphere and its effect upon regional climate. I. An aerological study of blocking action. Tellus, 2, 196-211, https://doi.org/10.1111/j.2153-3490.1950.tb00331.x.

Richardson, D., and Coauthors, 2012: Verification statistics and evaluations of ECMWF forecasts in 2011-2012. ECMWF Tech. Memo. 688, 51 pp., www .ecmwf.int/en/elibrary/11917-verification-statistics -and-evaluations-ecmwf-forecasts-2011-2012.

Riemer, M., and S. C. Jones, 2010: The downstream impact of tropical cyclones on a developing baroclinic wave in idealized scenarios of extratropical transition. Quart. J. Roy. Meteor. Soc., 136, 617-637, https:// doi.org/10.1002/qj.605.

Rodwell, M. J., and Coauthors, 2013: Characteristics of occasional poor medium-range weather forecasts for Europe. Bull. Amer. Meteor. Soc., 94, 1393-1405, https://doi.org/10.1175/BAMS-D-12-00099.1.

Schäfler, A., and F. Harnisch, 2015: Impact of the inflow moisture on the evolution of a warm conveyor belt. Quart. J. Roy. Meteor. Soc., 141, 299-310, https://doi .org/10.1002/qj.2360.

- M. Boettcher, C. M. Grams, M. Rautenhaus, H. Sodemann, and H. Wernli, 2014: Planning of aircraft measurements within a warm conveyor belt. Weather, 69, 161-166, https://doi.org/10.1002/wea.2245.

Schwierz, C., S. Dirren, and H. C. Davies, 2004: Forced waves on a zonally aligned jet stream. $J$. Atmos. Sci., 61, 73-87, https://doi.org/10.1175/1520 -0469(2004)061<0073:FWOAZA>2.0.CO;2.

Selz, T., and G. C. Craig, 2015: Upscale error growth in a high-resolution simulation of a summertime weather event over Europe. Mon. Wea. Rev., 143, 813-827, https://doi.org/10.1175/MWR-D-14-00140.1.

Sodemann, H., and A. Stohl, 2013: Moisture origin and meridional transport in atmospheric rivers and their association with multiple cyclones. Mon. Wea. Rev., 141, 2850-2868, https://doi.org/10.1175/MWR -D-12-00256.1.

Spensberger, C., and T. Spengler, 2014: A new look at deformation as a diagnostic for large-scale flow. $J$. Atmos. Sci., 71, 4221-4234, https://doi.org/10.1175 /JAS-D-14-0108.1. 
Sprenger, M., and Couthors, 2017: Global climatologies of Eulerian and Lagrangian flow features based on ERA-Interim. Bull. Amer. Meteor. Soc., 98, 1739-1748, https://doi.org/10.1175/BAMS -D-15-00299.1.

Szunyogh, I., Z. Toth, R. E. Morss, S. J. Majumdar, B. J. Etherton, and C. H. Bishop, 2000: The effect of targeted dropsonde observations during the 1999 Winter Storm Reconnaissance Program. Mon. Wea. Rev., 128, 3520-3537, https://doi.org/10.1175/1520 -0493(2000)128<3520:TEOTDO >2.0.CO;2.

Teubler, F., and M. Riemer, 2016: Dynamics of Rossby wave packets in a quantitative potential vorticitypotential temperature framework. J. Atmos. Sci., 73, 1063-1081, https://doi.org/10.1175/JAS-D-15 -0162.1 .

Thorpe, A. J., 2004: Weather forecasting: A centenary perspective. Weather, 59, 332-335, https://doi .org/10.1256/wea.87.04.

Vaughan, G., and Coauthors, 2015: Cloud banding and winds in intense European cyclones: Results from the DIAMET project. Bull. Amer. Meteor. Soc., 96, 249265, https://doi.org/10.1175/BAMS-D-13-00238.1.

Weissmann, M., R. Busen, A. Dörnbrack, S. Rahm, and O. Reitebuch, 2005: Targeted observations with an airborne wind lidar. J. Atmos. Oceanic Technol., 22, 1706-1719, https://doi.org/10.1175/JTECH1801.1.

— - and Coauthors, 2011: The influence of assimilating dropsonde data on typhoon track and midlatitude forecasts. Mon. Wea. Rev., 139, 908-920, https://doi .org/10.1175/2010MWR3377.1.

Wendisch, M., D. Müller, D. Schell, and J. Heintzenberg, 2001: An airborne spectral albedometer with active horizontal stabilization. J. Atmos. Oceanic Technol., 18, 1856-1866, https://doi.org/10.1175/1520-0426 (2001)018<1856:AASAWA >2.0.CO;2.

- , and Coauthors, 2016: The ACRIDICON-CHUVA campaign: Studying tropical deep convective clouds and precipitation over Amazonia using the new German research aircraft HALO. Bull. Amer. Meteor. Soc., 97, 1885-1908, https://doi.org/10.1175/BAMS -D-14-00255.1.

Wernli, H., 1997: A Lagrangian-based analysis of extratropical cyclones. II. A detailed case-study. Quart. J. Roy. Meteor. Soc., 123, 1677-1706, https://doi .org/10.1002/qj.49712354211.

—, and H. C. Davies, 1997: A Lagrangian-based analysis of extratropical cyclones. I. The method and some applications. Quart. J. Roy. Meteor. Soc., 123, 467-489, https://doi.org/10.1002/qj.49712353811.

— - and M. Sprenger, 2007: Identification and ERA15 climatology of potential vorticity streamers and cutoffs near the extratropical tropopause. J. Atmos. Sci., 64, 1569-1586, https://doi.org/10.1175/JAS3912.1.

Wirth, M., A. Fix, P. Mahnke, H. Schwarzer, F. Schrandt, and G. Ehret, 2009: The airborne multi-wavelength water vapor differential absorption lidar WALES: System design and performance. Appl. Phys., 96B, 201-213, https://doi.org/10.1007/s00340-009-3365-7. Witschas, B., S. Rahm, A. Dörnbrack, J. Wagner, and M. Rapp, 2017: Airborne wind lidar measurements of vertical and horizontal winds for the investigation of orographically induced gravity waves. $J$. Atmos. Oceanic Technol., 34, 1371-1386, https://doi .org/10.1175/JTECH-D-17-0021.1.

Wulfmeyer, V., and Coauthors, 2011: The Convective and Orographically Induced Precipitation Study (COPS): The scientific strategy, the field phase, and research highlights. Quart. J. Roy. Meteor. Soc., 137, 3-30, https://doi.org/10.1002/qj.752.

Zhang, F., N. Bei, R. Rotunno, C. Snyder, and C. C. Epifanio, 2007: Mesoscale predictability of moist baroclinic waves: Convection-permitting experiments and multistage error growth dynamics. $J$. Atmos. Sci., 64, 3579-3594, https://doi.org/10.1175 /JAS4028.1. 
AMS titles now

available as eBooks

at springer.com

\section{AMS BOOKS}

\section{RESEARCH APPLICATIONS HISTORY}

www.ametsoc.org/amsbookstore

Springer

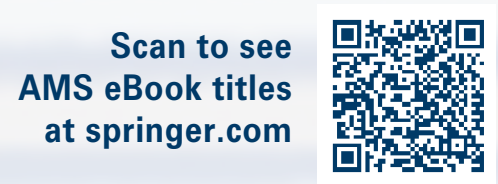

Springer

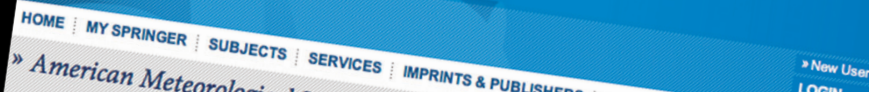

"American Meteorological SOCiety
"AOGW

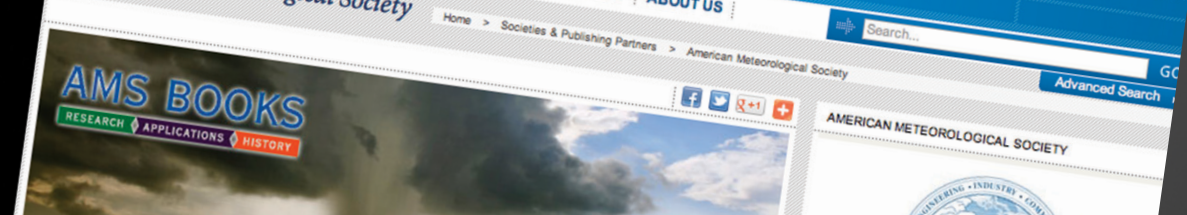

